\title{
Characteristics of randomized controlled trials of yoga: a bibliometric analysis
}

Holger Cramer ${ }^{*}$, Romy Lauche and Gustav Dobos

\begin{abstract}
Background: A growing number of randomized controlled trials (RCTs) have investigated the therapeutic value of yoga interventions. This bibliometric analysis aimed to provide a comprehensive review of the characteristics of the totality of available randomized yoga trials.

Methods: All RCTs of yoga were eligible. Medline/PubMed, Scopus, the Cochrane Library, IndMED, and the tables of content of yoga specialty journals not listed in medical databases were screened through February 2014. Bibliometric data, data on participants, and intervention were extracted and analyzed descriptively.

Results: Published between 1975 and 2014, a total of 366 papers were included, reporting 312 RCTs from 23 different countries with 22,548 participants. The median study sample size was 59 (range 8-410, interquartile range $=31$, 93). Two hundred sixty-four RCTs (84.6\%) were conducted with adults, 105 (33.7\%) with older adults and 31 (9.9\%) with children. Eighty-four RCTs (26.9\%) were conducted with healthy participants. Other trials enrolled patients with one of 63 varied medical conditions; the most common being breast cancer (17 RCTs, 5.4\%), depression (14 RCTs, 4.5\%), asthma (14 RCTs, 4.5\%) and type 2 diabetes mellitus (13 RCTs, 4.2\%). Whilst 119 RCTs (38.1\%) did not define the style of yoga used, 35 RCTs (11.2\%) used Hatha yoga and 30 RCTs (9.6\%) yoga breathing. The remaining 128 RCTs (41.0\%) used 46 varied yoga styles, with a median intervention length of 9 weeks (range 1 day to 1 year; interquartile range $=5,12)$. Two hundred and forty-four RCTs (78.2\%) used yoga postures, 232 RCTs (74.4\%) used breath control, 153 RCTs (49.0\%) used meditation and 32 RCTs (10.3\%) used philosophy lectures. One hundred and seventy-four RCTs (55.6\%) compared yoga with no specific treatment; 21 varied control interventions were used in the remaining RCTs.
\end{abstract}

Conclusions: This bibliometric analysis presents the most complete up-to-date overview on published randomized yoga trials. While the available research evidence is sparse for most conditions, there was a marked increase in published RCTs in recent years.

Keywords: Yoga, Complementary therapies, Randomized controlled trials, Bibliometrics, Review

\section{Background}

Yoga is rooted in Indian philosophy and has been a part of traditional Indian spiritual practice for millennia [1]. The Indian sage Patañjali prescribed adherence to eight limbs of yoga, aimed at quieting one's mind to achieve the union of mind, body and spirit that is traditional yoga's ultimate goal. These limbs include 'Yama' and 'Niyama' (a code of conduct for an ethical lifestyle), 'Asana' (physical postures), 'Pranayama' (breath control), 'Pratyahara' (withdrawal of the senses from external

\footnotetext{
* Correspondence: h.cramer@kliniken-essen-mitte.de

Department of Internal and Integrative Medicine, Kliniken Essen-Mitte, Faculty of Medicine, University of Duisburg-Essen, Am Deimelsberg 34a, 45276 Essen, Germany
}

objects to increase self-awareness), 'Dharana' (concentration), 'Dhyana' (meditation) and 'Samadhi' (oneness with the object of meditation) [1,2]. Regardless of its spiritual origins, yoga has become a popular route to physical and mental well-being [1,2] and has been adapted for use in complementary and alternative medicine in Western society [3]. In the latter setting, yoga is most often associated with physical postures, breath control and meditation; and different yoga schools have emerged that put varying focus on physical and mental practices [2].

Worldwide, it is estimated that yoga is regularly practiced by about 30 million people [4]. Yoga is gaining increased popularity as a therapeutic practice; nearly 
14 million Americans $(6.1 \%$ of the United States of America's population) reported that yoga had been recommended to them by a physician or therapist [5]. Indeed, about half of American yoga practitioners (more than 13 million people) reported starting practice explicitly to improve their health [6,7]. In the United Kingdom, yoga is even promoted by the National Health Service as a safe and effective approach, in health and illness, for people of all ages [8].

Yoga's therapeutic potential has been explored in a growing number of randomized controlled trials (RCTs) to date [9]. In order to inform practitioners, therapists and patients about the therapeutic value of yoga in a specific condition, it is important to consolidate knowledge on the available research evidence. The aim of this bibliometric analysis was to provide a comprehensive review of the characteristics of the totality of available randomized yoga trials.

\section{Methods}

Where applicable, this bibliometric analysis is reported in accordance with the PRISMA (Preferred Reporting Items for Systematic Reviews and Meta-Analyses) guidelines [10].

\section{Eligibility criteria \\ Types of studies}

Randomized controlled trials (RCTs), cluster-randomized trials and randomized cross-over studies were eligible. No language restrictions were applied.

\section{Types of participants}

Studies of all types of participants were eligible. No restrictions were applied regarding socio-demographic characteristics or health status.

\section{Types of interventions}

Studies were eligible if they assessed the effects of yoga interventions. No restrictions were applied regarding the tradition, length, frequency or duration of the studied yoga programs. The specific yoga practices included in the intervention were not restricted as long as the intervention was based on yoga theory and/or traditional yoga practice. Eligible intervention components included yoga postures, yoga breathing techniques and meditation, and lectures on yoga philosophy and/or yoga lifestyle. Studies that allowed individual co-interventions, in addition to the intervention formally studied were deemed eligible, but those with multimodal interventions (such as mindfulness-based stress reduction or comprehensive lifestyle modification) were not, even if the latter included yoga. Studies with all types of control interventions were deemed eligible.

\section{Literature search methods}

Four electronic databases, Medline/PubMed, Scopus, IndMED and the Cochrane Library were searched from their inception through February 12, 2014. The literature search was constructed around search terms for "yoga" and a filter for retrieving randomized controlled trials [11]. The complete search strategy for Medline/Pubmed is shown in Table 1. The reference lists of identified original articles or reviews were also searched manually for additional eligible studies. Additionally, the tables of contents of the Journal of Yoga E Physical Therapy and the International Scientific Yoga Journal SENSE were reviewed. Identified abstracts were screened independently by two review authors (RL, HC). Potentially eligible articles were then read in full by two review authors (HC, RL) to determine whether they actually met the eligibility criteria.

\section{Data extraction and analysis}

Bibliometric data (publication year, origin, journal of publication), data on participants (origin, sample size, gender, age, medical condition) and intervention (yoga tradition, program length, intervention components, control intervention) were extracted by the latter authors (HC,RL), using a standardized data extraction form. These data were then analyzed descriptively using SPSS $^{\oplus}$ (release 20.0, IBM, Armonk, NY, USA) and Microsoft Excel (version 12.3.5, Microsoft, Redmond, WA, USA), to determine their distribution, central tendency (median) and dispersion (range, interquartile range [IQR]).

\section{Results}

Literature search

A total of 2,488 records were located in the literature search, an additional 31 others being identified from other sources. Duplicate records were then excluded, leaving 1530 records to be screened. Of these, 1041 were excluded either because they were not randomized or because they did not include yoga as an intervention. Of the remaining 489 full-text records assessed for

\section{Table 1 Search strategy for PubMed/Medline \\ PubMed \\ \#1 Yoga [MeSH Terms] \\ \#2 Yoga* [Title/Abstract] OR Yogic [Title/Abstract] OR Pranayam* [Title/Abstract] OR Asana* [Title/Abstract] \\ \#3 \#1 OR \#2 \\ \#4 Randomized Controlled Trial [Publication Type] OR controlled clinical trial [Publication Type] OR randomized [Title/Abstract] OR placebo [Title/Abstract] OR random [Title/Abstract] OR randomly [Title/Abstract] OR trial [Title/Abstract] OR group [Title/Abstract] \\ \#5 \#3 AND \#4}

Asterisks $\left(^{*}\right)$ represent truncations (PubMed finds all terms that begin with a given text string). 
eligibility, 124 were excluded because either they were not fully published [12-26], were not randomized [27-115] or they did not include yoga interventions [116-134]. The final analysis was conducted on 366 fulltext articles [135-500] reporting 312 RCTS with a total of 22,548 participants (Figure 1 ).

\section{Bibliometrics}

The 366 analyzed articles originated in 23 different countries, with most coming from India $(\mathrm{k}=170,46.4 \%)$ or the USA $(k=98,26.8 \%)$. The two earliest pieces were published in 1975; but most (86.9\%) were published postmillennial. Between 2010 and 2011, and again between 2011 and 2012, the number of articles published each year almost doubled, and remained relatively stable from 2012 to 2013 (Figure 2). Of the 366 articles identified, 54 (14.8\%) proved to be duplicate publications (Figure 2); that is multiple articles reporting identical or different results on 28 already published studies; with only seven disclosing the existence of the latter. Of 170 Indian articles, only 136 were original publications, the remainder $(\mathrm{k}=34,20.0 \%)$ being duplicates of already published RCTs. Of the US publications, 11 pieces (11.2\%) were duplicated in this way. The 366 analyzed articles appeared in 155 different journals; the most prevalent being the International Journal of Yoga $(\mathrm{k}=27,7.4 \%)$, the Journal of Alternative and Complementary Medicine $(\mathrm{k}=21,5.7 \%)$, the Indian Journal of Physiology and Pharmacology $(\mathrm{k}=19,5.2 \%)$, Evidence-based Complementary and Alternative Medicine $(\mathrm{k}=9,2.5 \%)$, Complementary Therapies in Medicine $(\mathrm{k}=8,2.2 \%)$, the Indian Journal of Psychiatry $(\mathrm{k}=8,2.2 \%)$, the Journal of Yoga \& Physical Therapy ( $\mathrm{k}=7,1.9 \%)$, Alternative Therapies in Health and Medicine $(\mathrm{k}=6$, 2.2\%) and the Indian Journal of Medical Research $(\mathrm{k}=6$, 1.6\%). Two journals published five articles, four journals published four articles, eight journals published three articles and 29 journals published two articles apiece. The remaining 147 journals each published a single paper. In total, 42 articles were published in yoga specialty journals, 58 articles in journals specialized on complementary therapies or integrative medicine, and 193 in other journals including major general medicine journals like Lancet $(\mathrm{k}=2,0.7 \%)$ [370,429], JAMA $(\mathrm{k}=1,0.4 \%)$ [236], and Annals of Internal Medicine (k=2, 0.7\%) [425,464]. Almost all articles were written in English $(k=359,97.8 \%)$, with two each $(0.5 \%)$ in Japanese and Chinese and one each $(0.3 \%)$ in German, Polish, Portuguese and Farsi.

\section{Participants}

A total of 22,548 participants, from 23 different countries and five continents (Asia, North America, South America, Europe and Australia), took part in the 312 included RCTs (Figure 3). Study sample sizes ranged from 8-410 (median 59, IQR = 31, 93).

The proportion of female participants ranged from $0 \%$ (30 RCTs, 9.6\%) to $100 \%$ (81 RCTs, $26.1 \%$ ), with a median of $67.0 \%$ (IQR $=41.3 \%, 100.0 \%)$. Twenty-eight RCTs $(9.0 \%)$ did not report the proportion of female participants. Most

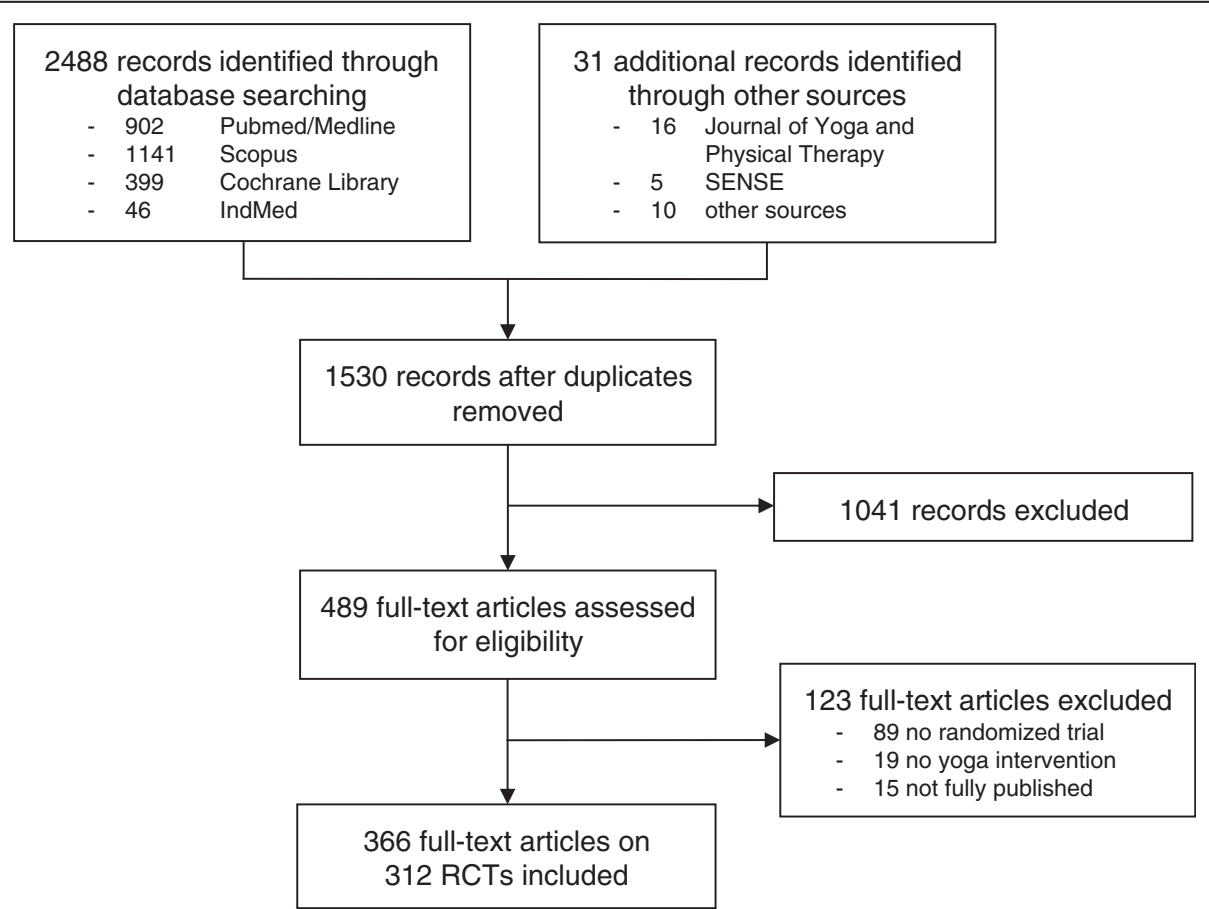

Figure 1 Results of the literature search. 


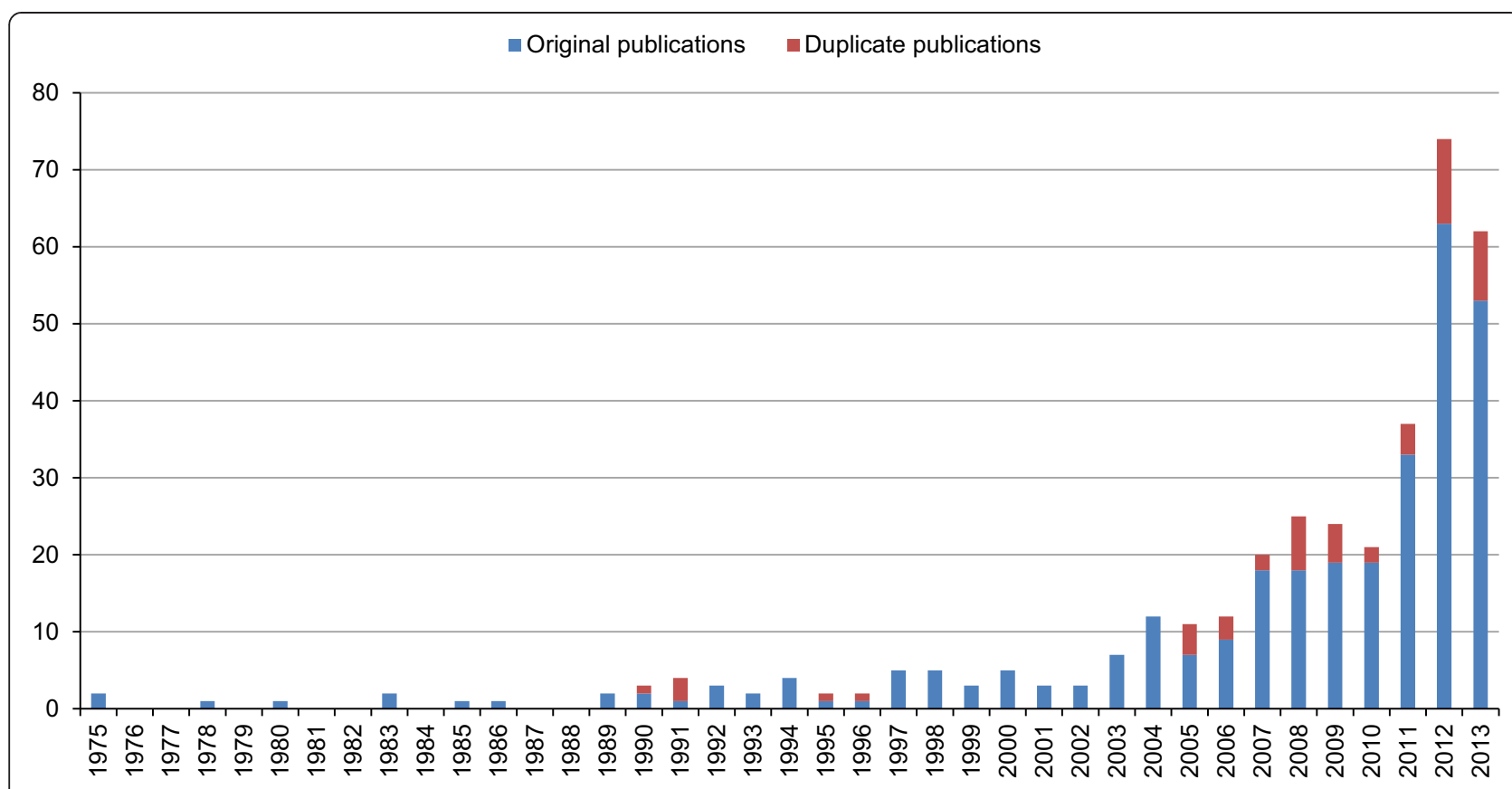

Figure 2 Year of publication. Numbers of publications between 1975 (year of first published RCT) and 2013 (last year completely covered by the literature search).
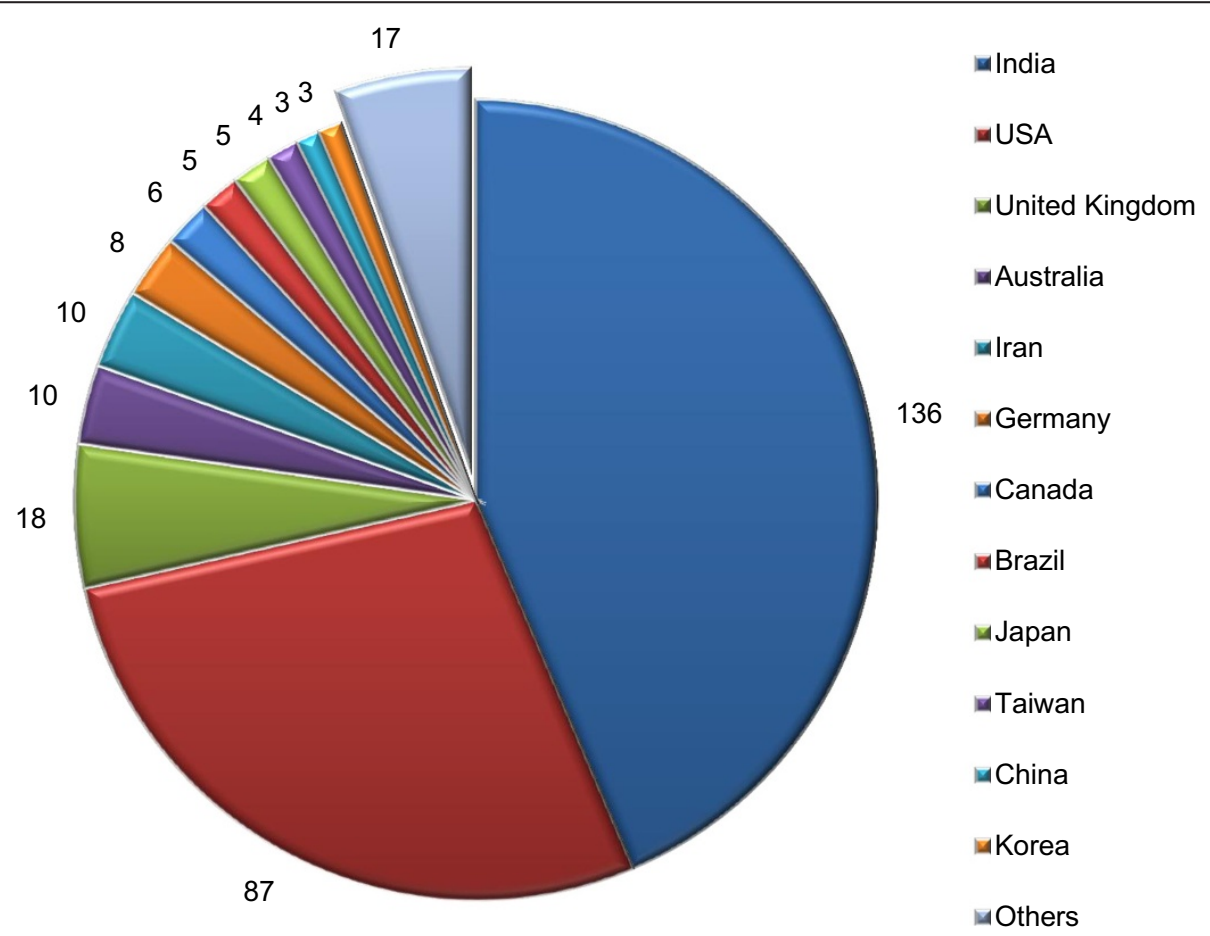

Figure 3 Origin of RCTs. Number of RCTs (not publications) classified according to country in descending order. Others = countries with just $1 \mathrm{RCT}$. 
studies (264 RCTs, 84.6\%) included adults (aged 18-64 years), with 169 of these enrolling only adults (54.2\%). Children and/or adolescents ( $<18$ years) were included in 31 RCTs (9.9\%), with 26 (8.3\%) of these enrolling only children. Older adults ( $\geq 65$ years) participated in 105 RCTs (33.7\%), with 14 (4.5\%) of these enrolling only older adults.

With regard to participants' health, 84 RCTs (26.9\%) were conducted only with healthy individuals. A further 23 RCTs (7.4\%) included participants from the general population, or from subpopulations such as students or employees, without any specified medical conditions as inclusion criteria. The remaining trials included participants with 63 varied predefined medical or mental health conditions (Figure 4). The most common disease categories were neurological or psychiatric disorders with 59 RCTs on 21 different conditions; spinal pain or rheumatologic diseases (7 conditions, 25 RCTs); and cardiovascular or metabolic diseases (7 conditions, 39 RCTs).

\section{Interventions}

Of the 312 included RCTs, 119 (38.1\%) did not define the specific style of yoga used. Thirty-five studies (11.2\%) stated that Hatha yoga was used; and 30 others (9.6\%) noted that Pranayama or yoga breathing was used, but failing to mention a specific yoga tradition. Of the RCTs that did cite a specific yoga style or approach, Iyengar yoga (31 RCTs, 9.9\%), the integrated approach to yoga (16 RCTs, 5.1\%) and Sudarshan Kriya yoga (8 RCTs, 2.6\%), appeared most often. The remaining 73

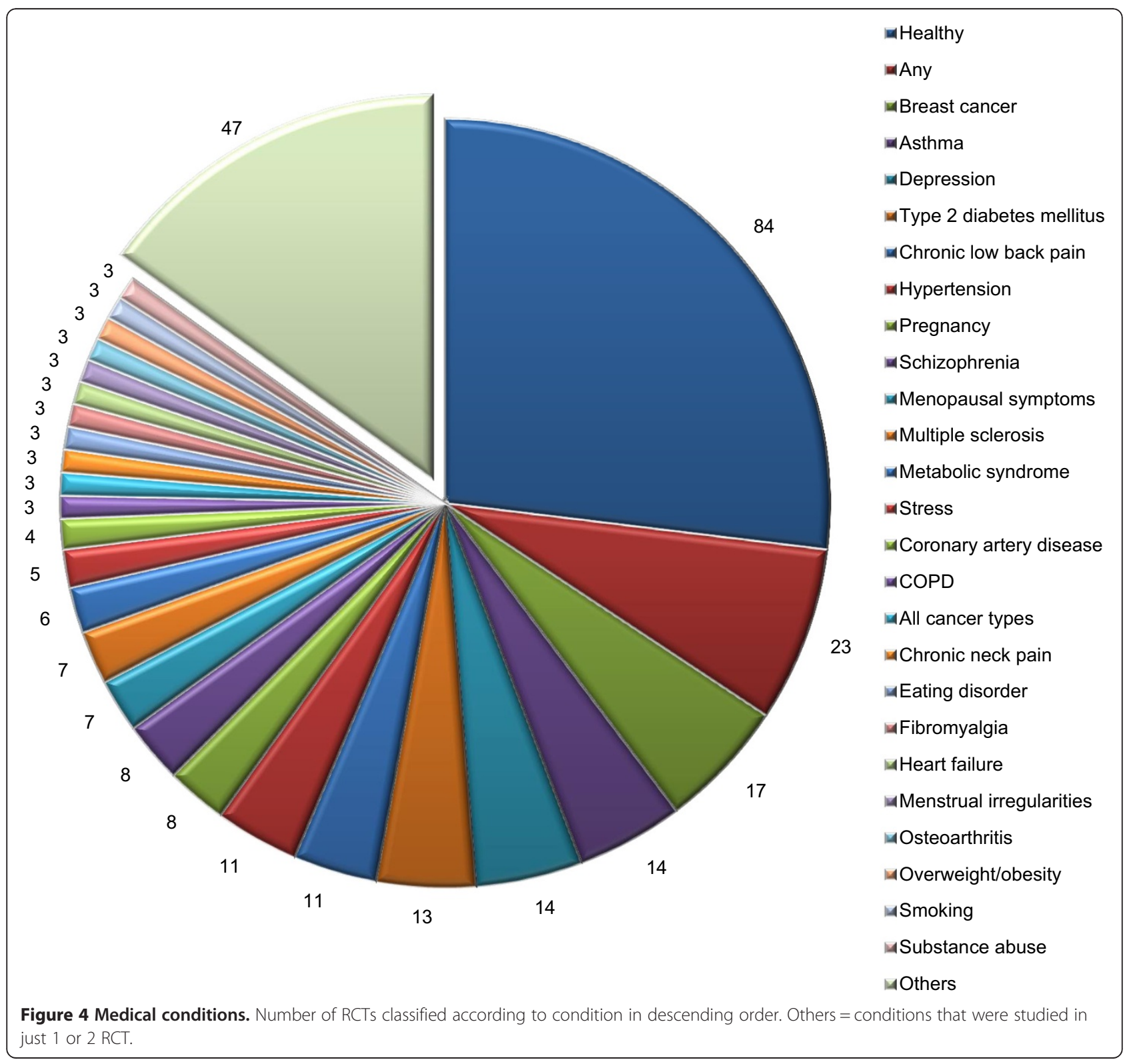


trials (23.4\%) cited 43 different yoga traditions (Figure 5). Two hundred and forty-four RCTs (78.2\%) included yoga postures in their yoga intervention; 232 RCTs (74.4\%) included yogic breathing techniques; and 153 RCTs (49.0\%) explicitly included meditation (mere relaxation was not counted as meditation). Lectures on yoga philosophy were included by 32 RCTs (10.3\%). The reported yoga interventions ranged in length from 1 day (14 RCTs, $4.5 \%$ ) to 1 year (4 RCT, 1.3\%), with a median length of 9 weeks (IQR $=5,12)$. Eight (50 RCTs, 16.0\%) and twelve (68 RCTs, 21.8\%) week programs were by far the most common.

Most RCTs compared yoga to one control intervention (or multiple variants of the same control condition), but 62 trials (19.4\%) specified two or more different control interventions. In total, 21 different categories of control interventions appeared. More than half of the reported trials cited usual care or no specific treatment as their controls (174 RCTs, 55.8\%). Exercise (65 RCTs, 10.1\%), other forms of yoga (24 RCTs, 7.7\%), and interventions designed to control for the non-specific effects of yoga, such as increased attention by therapists and/or other participants, but without expected specific effects (19 RCTs, 6.1\%), were the most commonly used active control conditions (Figure 6).

\section{Discussion}

This bibliometric analysis of the totality of available randomized controlled yoga trials included 312 RCTs from 23 countries, conducted with a total of 22,548 participants. Whilst the earliest of these studies appeared in
1975 , the vast majority were post-millennial. The years 2011 and 2012 proved particularly fruitful. Although there was a slight decrease in 2013, the total number of studies published in 2013 is still three times as high as in 2010; suggesting increasing research evidence for yoga in the future. Whether this really marks a trend towards researchers being increasingly intrinsically interested in yoga research or just a policy or funding change remains unclear.

In 2004, an earlier bibliometric analysis of all published yoga trials included 72 RCTs. More than half of these trials originated in India; more than twice as many trials as had then been conducted in the USA [9]. In contrast, the number of Indian and American RCTs in the present analysis was more balanced. Note should be taken, however, of the high number of duplicate Indian yoga publications; suggesting greater than actual Indian research activity. Such duplication increases the risk of falsely overestimating the available evidence for yoga's effects considerably. This trend towards increased yoga research outside India is important, given previouslyvoiced concerns about the quality of Indian trials' research methods and Indian journals' peer review processes [9]. In addition, Indian yoga trial results may not apply fully to Western societies, as yoga is often seen as a spiritual intervention by Indian participants and as a sport or wellness intervention elsewhere [2,3]. Systematic reviews also found that Indian yoga trials frequently use extremely time-consuming interventions that may not be feasible in Western participant samples [501]. Accordingly, all four trials with a 1-year intervention

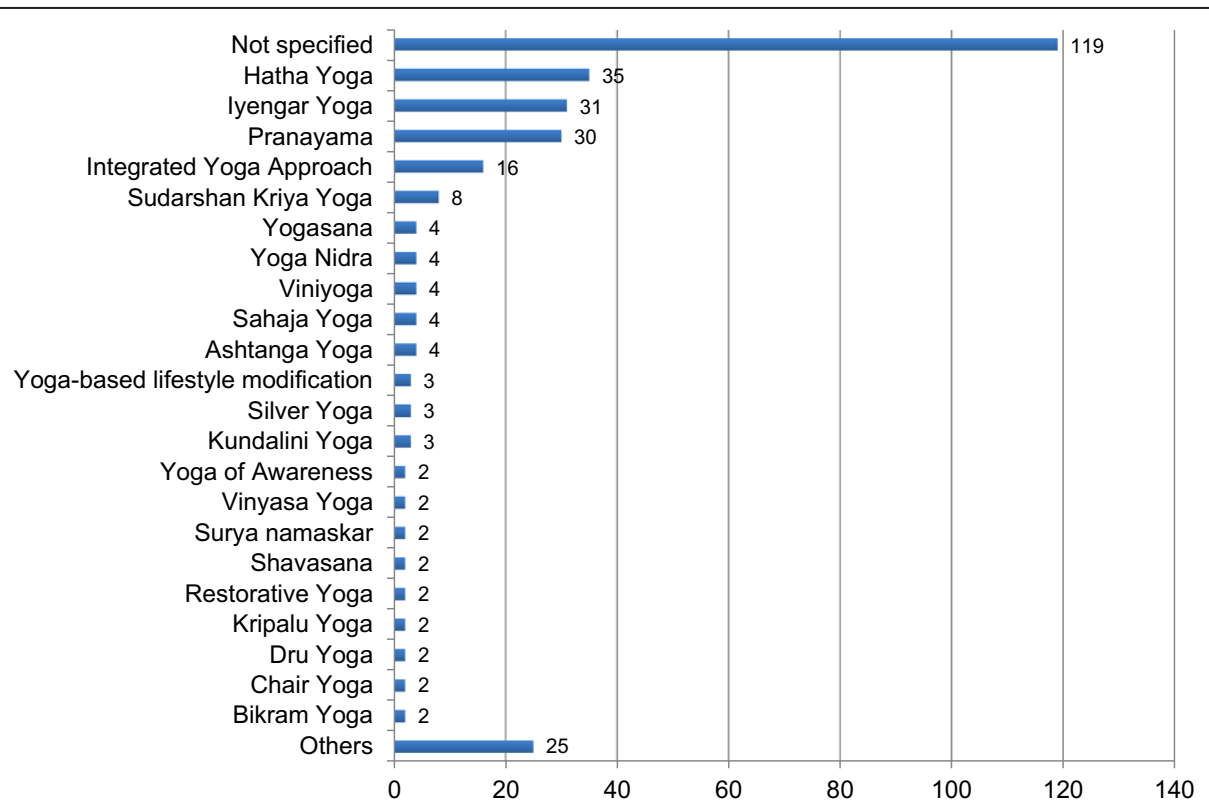

Figure 5 Yoga styles. Number of RCTs classified according to yoga style uses in the intervention. Others =yoga styles that were used in just $1 \mathrm{RCT}$. 


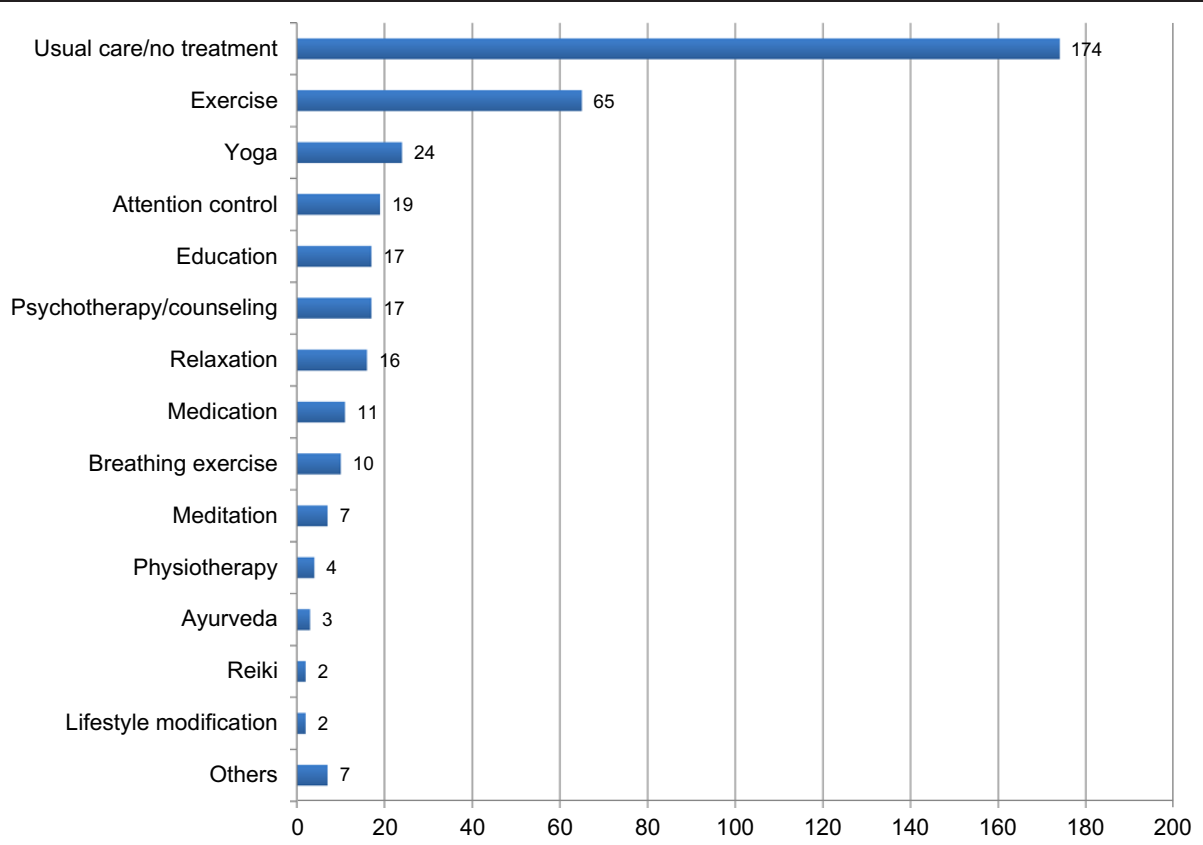

Figure 6 Control interventions. Number of RCTs classified according to control intervention. Others = control interventions that were used in just 1 RCT.

period included in this analysis were conducted in India. Trials conducted in the USA or Europe may apply more fully to participants from these cultural backgrounds, as a result.

The analyzed studies had a median of 59 participants, most of them female adults. About a third of these studies were conducted with healthy participants, or those not selected on the basis of their health status. The most commonly included conditions in the remaining RCTs were breast cancer, asthma, depression, type 2 diabetes mellitus, low back pain and hypertension. While this bibliometric analysis does not aim to gauge yoga's effectiveness as an intervention it seems important to systematically assess the level of evidence provided by these RCTs. Accordingly, a recent meta-analysis included all available 14 RCTs on yoga for asthma. This meta-analysis found short-term beneficial effects on asthma symptoms and pulmonary function [502]. Although not all RCTs available to date were included, systematic reviews and meta-analyses also exist for breast cancer [503,504], depression [505,506], type 2 diabetes $[507,508]$, chronic low back pain $[509,510]$, hypertension [511-513], pregnancy [514], schizophrenia [515], menopausal symptoms [501,516], multiple sclerosis [517], and others but not all of the more frequently studied conditions. E.g. to the best of our knowledge, no systematic review on yoga for overweight/obesity is available today. Other RCTs have investigated yoga's effects in healthy participants, with some comparing different yoga forms $[157,279,348,379,449,450]$, the immediate effects of single yoga interventions $[279,379,456]$ or the mechanisms by which yoga interventions might work [438]. Such RCTs may yield useful information about yoga's effects and potential mechanisms also for patients with specific medical conditions.

This bibliometric analysis found that the available research evidence has continuously increased in the past years, especially in recent years, but more research is clearly needed. Whilst 26 medical conditions have appeared in one or two RCTs to date, only six have appeared in ten or more. Indeed, only 17, 14, and 14 RCTs have focused on breast cancer, asthma, and depression, respectively, the most commonly-studied conditions. Despite the fact that many of these studies have found positive effects, yoga research clearly remains limited for most conditions. Besides primary research, up-to-date systematic reviews and meta-analyses are needed at least for the most commonly studied conditions in order to evaluate the level of evidence and strength of recommendation for or against the use of yoga in each condition.

More than 40 different yoga styles were used in the analyzed RCTs. Whilst most trials included yoga postures and breathing, yoga meditation and philosophy were less often used. Yoga is, by definition, a multimodal practice [2,3]. Although exercise is now often seen as yoga's main component in Western society, meditation, breathing and lifestyle advice are all traditionally accounted at least equally important [3]. In gauging yoga's effectiveness, it is important to note that studied interventions can range from the purely meditative to the 
purely physical in nature. The effects of such diverse interventions are hardly directly comparable, making research to determine the best balance for different medical conditions valuable.

Yoga is not a standardized intervention, nor is it likely (or arguably desirable) that it should become one. This diversity makes it challenging to convey the nature of 'best' practice for inclusion in medical guidelines or patient recommendations. The extent to which recent guidelines for designing yoga interventions [518] and control conditions [519] in clinical trials will increase the homogeneity of future research remains unclear. The above evidence suggests that future research might usefully explore the separate effects of yoga postures, breath control, meditation and lifestyle advice, to determine the best interventions for different medical conditions.

This bibliometric analysis has a number of limitations. Firstly, despite the rigorous literature search conducted, it is likely that some RCTs have been missed. Several Indian journals and in particular yoga specialty journals might not be indexed even in Indian medical databases [9]. Secondly, as yoga encompasses a wide variety of practices, borders are blurred between yoga and other, similar, interventions. For example, transcendental meditation is usually seen as distinct from yoga, but is actually based on yoga principles [520]. In the same way, mindfulness-based stress reduction uses yoga postures, but is not commonly seen as a yoga intervention [521]. The exclusion of such interventions from this analysis may, thus, be seen as arbitrary. Thirdly, outcome measures and length of follow-up for outcome assessment were not assessed in this analysis. Finally, this review did not evaluate yoga's effectiveness or the included trials' methodological quality. The mere existence of RCTs on a specific condition should not be misinterpreted as evidence of effectiveness in this condition. An in depth study of the located RCTs and - if available - systematic reviews on the effectiveness of these RCTs in a specific condition are necessary to judge the therapeutic value of yoga in this condition. An important next step would be to determine the methodological quality, i.e. risk of bias, nature of outcomes, etc., of the current body of RCTs.

Future yoga research should focus on investigating yoga's efficacy and safety in conditions that have a major impact on society. Multiple RCTs on the same condition are needed in order to be able to conclusively evaluate its efficacy in this patient population. While it might sometimes be useful to separately publish multiple subanalyses or reanalyses on the same RCT, simply splitting up outcomes of a single RCT to several publications can be regarded as a violation of research ethics - especially if this practice is not disclosed in the respective publications. If a duplicate publication is considered necessary, the authors should disclose and justify this practice in all of the respective publications. Beyond further RCTs, upto-date systematic reviews and meta-analyses are needed that consolidate the evidence of single RCTs. These reviews should strive to include the totality of available RCTs on a given condition; and probably also an assessment of whether the included RCTs meet recent guidelines for conducting yoga research $[518,519]$.

\section{Conclusion}

This bibliometric analysis presents the most complete up-to-date review of the randomized controlled yoga trials published to date, and can serve to inform patients, therapists, and researchers on the available yoga research evidence. The results show a marked rise in the number of such trials in recent years; based on research increasingly conducted outside India. For almost four decades, researchers have compared a range of diverse yoga interventions and control conditions, in varied participant samples. This research has had its limitations, with most trials being relatively small in size and failing to explore even common medical conditions frequently. However, this analysis suggests that yoga-based RCTs will increase, diversify and hopefully flourish in future years.

\section{Competing interests}

The authors declare that they have no competing interests.

\section{Authors' contributions}

$\mathrm{HC}$ was responsible for conception and design of the review, participated in the literature search, performed data extraction, data analysis, and drafted the manuscript. $R L$ participated in conception and design of the review, carried out the literature search, performed data extraction, and critically revised the manuscript. GD critically revised the manuscript. All authors read and approved the final manuscript.

\section{Acknowledgements}

The authors express their gratefulness to Dr. Petra Klose for her help in assessing the Chinese and Japanese manuscripts; and to Dr. Susan Rugg for her help in language editing.

Received: 10 July 2013 Accepted: 19 August 2014 Published: 2 September 2014

\section{References}

1. Iyengar BKS: Light on Yoga. New York: Schocken Books; 1966. Feuerstein G: The Yoga Tradition. Prescott: Hohm Press; 1998.

3. De Michaelis E: A History of Modern Yoga: Patanjali and Western Esotericism. London, UK: Continuum International Publishing Group; 2005.

4. Dangerfield A: Yoga wars. BBC news magazine. 2009. 23 January 2009. Available: http://news.bbc.co.uk/1/hi/7844691.stm. Accessed 20 February 2013.

5. Macy D: Yoga journal releases 2008 "Yoga in America" market study. Yoga J 2008. Available: http://www.yogajournal.com/advertise/ press_releases/10. Accessed 20 February 2013.

6. Barnes PM, Bloom B, Nahin RL: Complementary and alternative medicine use among adults and children: United States, 2007. Natl Health Stat Report 2008, 12:1-23.

7. Barnes PM, Powell-Griner E, McFann K, Nahin RL: Complementary and alternative medicine use among adults: United States, 2002. Adv Data 2004, 343:1-19.

8. NHS: Your health, your choices. A guide to yoga. 2013. Available: http://www.nhs.uk/livewell/fitness/pages/yoga.aspx. Accessed 20 February 2013.

9. Khalsa SB: Yoga as a therapeutic intervention: a bibliometric analysis of published research studies. Indian J Physiol Pharmacol 2004, 48(3):269-285. 
10. Moher D, Liberati A, Tetzlaff J, Altman DG: Preferred reporting items for systematic reviews and meta-analyses: the PRISMA statement. BMJ 2009, 339:b2535.

11. Higgins JPT, Green S: Cochrane Handbook for Systematic Reviews of Interventions. West Sussex: John Wiley \& Sons Ltd; 2008

12. Ajaikumar BS, Raghavendra RM, Patil S, Ravi DB, Srinath SB, Gopinath KS, Nagarathna R: Antidepressant effects of a yoga program in breast cancer patients undergoing conventional treatment: a randomized controlled trial [abstract no. 9556]. J Clinical Oncol: ASCO annual meeting proceedings 2008, 26:515.

13. Annapoorna K, Latha KS, Bhat SM, Bhandary PV: Effectiveness of the practice of yoga therapy in anxiety disorders: a randomized controlled trial [conference abstract]. Asian J Psychiatry 2011, 4(Suppl 1):S45.

14. Baker J: Mindfulness-Based Stress Reduction Techniques and Yoga for treatment of urinary urge incontinence (MBSR-Yoga) (Trials Registry number: NCT01470560). 2011, (http://clinicaltrials.gov).

15. Blom K, Baker B, How M, Dai M, Abbey S, Myers M: Hypertension analysis of stress reduction using mindfulness meditation and yoga: Results from a randomized controlled trial [abstract]. Can J Cardiol 2012 28(5 Suppl 1):S418-s419.

16. Blom KC, Baker B, Irvine J, Abbey S, Abramson B, Myers M, Perkins N, Tobe SW: The harmony study: hypertension analysis of stress reduction using mindfulness meditation and yoga. J Clin Hypertens 2011, 13(4 Suppl 1):A141.

17. Carei Tiffany R: Randomized controlled clinical trial of yoga in the treatment of eating disorders. Diss Abstr Int 2008, 68(8-b):5560.

18. Cohen L, Chandwani K, Thornton B, Perkins G: Randomized trial of yoga in women with breast cancer undergoing radiation treatment. J Clin Oncol 2006, 24(18 Suppl):469s.

19. Cohen L, Chandwani KD, Perkins G, Thornton B, Arun B, Raghuram NV Nagendra HR: Randomized trial of yoga in women with breast cancer undergoing radiation treatment: Long-term effects [abstract no. 9639]. J Clinical Oncol: ASCO annual meeting proceedings 2008, 26(15S):9639.

20. Innes K, Taylor TSGACBA, Hinton I: Effects of yoga on sleep, mood, and related outcomes in older women with restless legs syndrome: a nested randomized controlled trial (RCT) [abstract]. BMC Complement Altern Med 2012, 12(Suppl 1):055.

21. Kalayil JA: A controlled comparison of progressive relaxation and yoga meditation as methods to relieve stress in middle grade school children. Diss Abstr Int 1989, 49(12):3626.

22. LaCroix AZ, Sternfeld B, Caan B, Newton KM, Reed SD, Cohen L: Results from the MsFLASH randomized controlled trial of yoga, aerobic exercise \& omega-3 supplementation for relief of vasomotor symptoms. Menopause (New York, NY) 2012, 19(12):1402-1403.

23. McDermott K: A pilot randomized controlled trial of yoga for prediabetes [abstract]. BMC Complement Altern Med 2012, 12(Suppl 1):P180.

24. Mustian KM, Sprod L, Peppone $\amalg$, Mohile SG, Janelsins MC, Palesh O: Effect of YOCAS yoga on circadian rhythm, anxiety, and mood: A URCC CCOP randomized, controlled clinical trial among 410 cancer survivors [abstract]. J Clin Oncol 2011, [abstracts of the ASCO annual meeting; 2011 jun 3-7; chicago, IL united states].

25. Sivaraman A: Yoga breathing exercise to reduce postoperative pulmonary complications in patients undergoing elective valve replacement for valvular heart disease: a randomized clinical trial. Heart Surgery Forum 2010, 13(Supplement 2):S83.

26. Wolfgang WJ, Mayer-Berger J, Kettner C, Pieper C, Marr A, Braeutigam U, Michalsen A, Moebus S: Randomized controlled trial of long-term use of yoga and progressive relaxation in cardiovascular rehabilitation. Eur J Cardiovasc Prev Rehabil 2010, 17:S58.

27. Anderzen-Carlsson A, Persson Lundholm U, Kohn M, Westerdahl E: Medical yoga: another way of being in the world-a phenomenological study from the perspective of persons suffering from stress-related symptoms. Int J Qual Stud Health Well-being 2014, 9:23033.

28. Arya V, Gupta KA, Arya SV: Efficacy of bolus lukewarm saline and yoga postures as colonoscopy preparation: a pilot study. J Altern Complement Med 2010, 16(12):1269-1277.

29. Badsha H, Chhabra V, Leibman C, Mofti A, Kong KO: The benefits of yoga for rheumatoid arthritis: results of a preliminary, structured 8-week program. Rheumatol Int 2009, 29(12):1417-1421.

30. Bankar MA, Chaudhari SK, Chaudhari KD: Impact of long term Yoga practice on sleep quality and quality of life in the elderly. J Ayurveda Integr Med 2013, 4(1):28-32.
31. Bedekar N, Prabhu A, Shyam A, Sancheti K, Sancheti P: Comparative study of conventional therapy and additional yogasanas for knee rehabilitation after total knee arthroplasty. Int J Yoga 2012, 5(2):118-122.

32. Berger DL, Silver EJ, Stein RE: Effects of yoga on inner-city children's well-being: a pilot study. Altern Ther Health Med 2009, 15(5):36-42.

33. Bernardi L, Sleight P, Bandinelli G, Cencetti S, Fattorini L, Wdowczyc-Szulc J, Lagi A: Effect of rosary prayer and yoga mantras on autonomic cardiovascular rhythms: Comparative study. Br Med J 2001, 323(7327):1446-1449.

34. Bindal VD, Ghai GD: Comparative efficacy of selected physiotherapy treatment and yogic asanas on low back pain among male physical education students. J Exercise Science and Physiotherapy 2007, 3(2):160-164.

35. Bosch PR, Traustadottir T, Howard P, Matt KS: Functional and physiological effects of yoga in women with rheumatoid arthritis: a pilot study. Altern Ther Health Med 2009, 15(4):24-31.

36. Bukowski EL, Conway A, Glentz LA, Kurland K, Galantino ML: The effect of iyengar yoga and strengthening exercises for people living with osteoarthritis of the knee: a case series. Int Q Community Health Educ 2006, 26(3):287-305.

37. Bulavin W, Kliuzhev VM, Kliachkin LM, Lakshmankumar ZND, Vlasova TN: Elements of yoga therapy in the combined rehabilitation of myocardial infarct patients in the functional recovery period. Vopr Kurortol Fizioter Lech Fiz Kult 1993, 4:7-9.

38. Burkhart J, McKenna M, Hill J: Wiitm yoga Vs. A traditional exercise program. J Yoga Phys Ther 2012, 2:116.

39. Cadmus-Bertram L, Littman AJ, Ulrich CM, Stovall R, Ceballos RM, McGregor BA, Wang CY, Ramaprasad J, McTiernan A: Predictors of adherence to a 26-week viniyoga intervention among post-treatment breast cancer survivors. J Altern Complement Med 2013, 19(9):751-758.

40. Cebria IIMD, Tortosa-Chulia MA, Igual-Camacho C, Sancho P, Galiana L, Tomas JM: Cost-consequence analysis of respiratory preventive intervention among institutionalized older people: randomized controlled trial. Rev Esp Geriatr Gerontol 2014.

41. Cheema BS, Marshall PW, Chang D, Colagiuri B, Machliss B: Effect of an office worksite-based yoga program on heart rate variability: a randomized controlled trial. BMC Public Health 2011, 11:578.

42. Cheong KJ, Lim SA: Antioxidant effects of regular yoga training on the healthy university students controlled clinical trial. J Yoga Phys Ther 2012, 2(6):127.

43. Chuang LH, Soares MO, Tilbrook H, Cox H, Hewitt CE, Aplin J, Semlyen A, Trewhela A, Watt I, Torgerson DJ: A pragmatic multicentered randomized controlled trial of yoga for chronic low back pain: economic evaluation. Spine (Phila Pa 1976) 2012, 37(18):1593-1601.

44. Chung SC, Brooks MM, Rai M, Balk JL, Rai S: Effect of Sahaja yoga meditation on quality of life, anxiety, and blood pressure control. J Altern Complement Med 2012, 18(6):589-596.

45. Cohen L: Randomized controlled trial of yoga among a multiethnic sample of breast cancer patients: effects on quality of life. Breast Diseases 2008, 19(2):129.

46. Coote S, Garrett M, Hogan N, Larkin A, Saunders J: Getting the balance right: a randomised controlled trial of physiotherapy and Exercise Interventions for ambulatory people with multiple sclerosis. BMC Neurol 2009, 9:34.

47. Cramer H, Lauche R, Haller H, Langhorst J, Dobos G, Berger B: "I'm more in balance": a qualitative study of yoga for patients with chronic neck pain. J Altern Complement Med 2013, 19(6):536-542.

48. Cramer H, Lauche R, Hohmann C, Langhorst J, Dobos G: Yoga for chronic neck pain: a 12-month follow-up. Pain Med 2013, 14(4):541-548.

49. Danhauer SC, Tooze JA, Farmer DF, Campbell CR, McQuellon RP, Barrett R, Miller BE: Restorative yoga for women with ovarian or breast cancer: findings from a pilot study. J Soc Integr Oncol 2008, 6(2):47-58.

50. Dash $M$, Telles S: Yoga training and motor speed based on a finger tapping task. Indian J Physiol Pharmacol 1999, 43(4):458-462.

51. Datey KK, Deshmukh SN, Dalvi CP, Vinekar SL: "Shavasan": a yogic exercise in the management of hypertension. Angiology 1969, 20(6):325-333.

52. de Godoy DV, Bringhenti RL, Severa A, de Gasperi R, Poli LV: Yoga versus aerobic activity: effects on spirometry results and maximal inspiratory pressure. J Bras Pneumol 2006, 32(2):130-135.

53. Dhameja K, Singh S, Mustafa MD, Singh KP, Banerjee BD, Agarwal M, Ahmed RS: Therapeutic effect of yoga in patients with hypertension with reference to GST gene polymorphism. J Altern Complement Med 2013, 19(3):243-249. 
54. Dhananjai S, Sadashiv TS, Dutt K, Kumar R: Reducing psychological distress and obesity through Yoga practice. Int J Yoga 2013, 6(1):66-70.

55. Dhikav V, Karmarkar G, Gupta M, Anand KS: Yoga in premature ejaculation: a comparative trial with fluoxetine. J Sex Med 2007, 4(6):1726-1732.

56. do Rosario JL, Orcesi LS, Kobayashi FN, Aun AN, Diolindo Assumpcao IT, Blasioli GJ, Hanada ES: The immediate effects of modified Yoga positions on musculoskeletal pain relief. J Bodyw Mov Ther 2013, 17(4):469-474.

57. Donesky D, Melendez M, Nguyen HQ, Carrieri-Kohlman V: A responder analysis of the effects of yoga for individuals with COPD: who benefits and how? Int J Yoga Therap 2012, 22:23-36.

58. Elavsky S, McAuley E: Lack of perceived sleep improvement after 4-month structured exercise programs. Menopause 2007, 14(3 Pt 1):535-540.

59. Elavsky S, McAuley E: Personality, menopausal symptoms, and physical activity outcomes in middle-aged women. Pers Individ Dif 2009, 46(2):123-128.

60. Fan JT, Chen KM: Using silver yoga exercises to promote physical and mental health of elders with dementia in long-term care facilities. Int Psychogeriatr 2011, 23(8):1222-1230.

61. Fields KB: Effects of brief yoga exercises and motivational preparatory interventions in distance runners: results of a controlled trial: commentary. Br J Sports Med 2006, 40(1):63.

62. Flegal KE, Kishiyama S, Zajdel D, Haas M, Oken BS: Adherence to yoga and exercise interventions in a 6-month clinical trial. BMC Complement Altern Med 2007, 7:37.

63. Garrett M, Hogan N, Larkin A, Saunders J, Jakeman P, Coote S: Exercise in the community for people with multiple sclerosis-a follow-up of people with minimal gait impairment. Mult Scler 2013, 19(6):790-798.

64. Ghasemi GA, Golkar A, Marandi SM: Effects of hata yoga on knee osteoarthritis. Int J Prev Med 2013, 4(Suppl 1):S133-S138.

65. Goncalves LC, Vale RG, Barata NJ, Varejao RV, Dantas EH: Flexibility, functional autonomy and quality of life (QoL) in elderly yoga practitioners. Arch Gerontol Geriatr 2011, 53(2):158-162.

66. Haslock I, Monro R, Nagarathna R, Nagendra HR, Raghuram NV: Measuring the effects of yoga in rheumatoid arthritis [3]. Br J Rheumatol 1994, 33(8):787-788

67. Hegde SV, Adhikari P, Kotian S, Pinto VJ, D'Souza S, D'Souza V: Effect of 3-month yoga on oxidative stress in type 2 diabetes with or without complications: A controlled clinical trial. Diabetes Care 2011, 34(10):2208-2210.

68. Huang A: Lessening Incontinence by Learning Yoga (LILY) (Trials registry number: NCT01672190). ClinicalTrials gov 2012. http://clinicaltrials.gov

69. Johnson Premkumar C: Effect of selected hathayogic practices in enhancing kicking ability in soccer playing. J Exercise Sci Physiother 2007, 3(2):168-170.

70. Kandula NR, Patel Y, Dave S, Seguil P, Kumar S, Baker DW, Spring B, Siddique J: The South Asian Heart Lifestyle Intervention (SAHELI) study to improve cardiovascular risk factors in a community setting: Design and methods. Contemp Clin Trials 2013, 36(2):479-487.

71. Katzman MA, Vermani M, Gerbarg PL, Brown RP, lorio C, Davis M, Cameron C, Tsirgielis D: A multicomponent yoga-based, breath intervention program as an adjunctive treatment in patients suffering from generalized anxiety disorder with or without comorbidities. Int J Yoga 2012, 5(1):57-65.

72. Kauts A, Sharma N: Effect of yoga on academic performance in relation to stress. Int J Yoga 2009, 2(1):39-43.

73. Khalsa SB, Butzer B, Shorter SM, Reinhardt KM, Cope S: Yoga reduces performance anxiety in adolescent musicians. Altern Ther Health Med 2013, 19(2):34-45.

74. Khemka SS, Rao NH, Nagarathna R: Immediate effects of two relaxation techniques on healthy volunteers. Indian J Physiol Pharmacol 2009, 53(1):67-72

75. Kjellgren A, Bood SA, Axelsson K, Norlander T, Saatcioglu F: Wellness through a comprehensive yogic breathing program - a controlled pilot trial. BMC Complement Altern Med 2007, 7:43

76. Kochupillai V, Kumar P, Singh D, Aggarwal D, Bhardwaj N, Bhutani M, Das SN: Effect of rhythmic breathing (Sudarshan Kriya and Pranayam) on immune functions and tobacco addiction. Ann N Y Acad Sci 2005, 1056:242-252

77. Kyizom T, Singh S, Singh KP, Tandon OP, Kumar R: Effect of pranayama \& yoga-asana on cognitive brain functions in type 2 diabetes-P3 event related evoked potential (ERP). Indian J Med Res 2010, 131:636-640.

78. Lakkireddy D, Atkins D, Pillarisetti J, Ryschon K, Bommana S, Drisko J, Vanga S, Dawn B: Effect of yoga on arrhythmia burden, anxiety, depression, and quality of life in paroxysmal atrial fibrillation: the YOGA My Heart Study. J Am Coll Cardiol 2013, 61(11):1177-1182.

79. Loudon A, Barnett T, Piller N, Immink MA, Visentin D, Williams AD: The effect of yoga on women with secondary arm lymphoedema from breast cancer treatment. BMC Complement Altern Med 2012, 12:66.

80. Madanmohan MSK, Balakrishnan S, Gopalakrishnan M, Prakash ES: Effect of six weeks yoga training on weight loss following step test, respiratory pressures, handgrip strength and handgrip endurance in young healthy subjects. Indian J Physiol Pharmacol 2008, 52(2):164-170.

81. Madanmohan UK, Bhavanani AB, Vijayalakshmi P, Surendiran A: Effect of slow and fast pranayams on reaction time and cardiorespiratory variables. Indian J Physiol Pharmacol 2005, 49(3):313-318.

82. Mahapure HH, Shete SU, Bera TK: Effect of yogic exercise on super oxide dismutase levels in diabetics. Int J Yoga 2008, 1(1):21-26.

83. Malathi A, Parulkar VG: Effect of yogasanas on the visual and auditory reaction time. Indian J Physiol Pharmacol 1989, 33(2):110-112.

84. Malhotra V, Singh S, Singh KP, Gupta P, Sharma SB, Madhu SV, Tandon OP: Study of yoga asanas in assessment of pulmonary function in NIDDM patients. Indian J Physiol Pharmacol 2002, 46(3):313-320.

85. Malhotra V, Singh S, Tandon OP, Madhu SV, Prasad A, Sharma SB: Effect of Yoga asanas on nerve conduction in type 2 diabetes. Indian J Physiol Pharmacol 2002, 46(3):298-306.

86. Manjunath NK, Telles S: Spatial and verbal memory test scores following yoga and fine arts camps for school children. Indian J Physiol Pharmacol 2004, 48(3):353-356.

87. Mclver S: Yoga may help manage binge eating disorder. Focus Altern Complement Ther 2010, 15(1):43-44.

88. Mizuno J, Monteiro HL: An assessment of a sequence of yoga exercises to patients with arterial hypertension. J Bodyw Mov Ther 2013, 17(1):35-41.

89. Moemeni M, Iranshahi F, Ramezani N, Amirabadi F, Ghahri M: Effect of yoga training on attention and anxiety preschool children. Life Science J 2012, 9(2):1133-1137.

90. Nambi GS, Shah AA: Additional effect of iyengar yoga and EMG biofeedback on pain and functional disability in chronic unilateral knee osteoarthritis. Int J Yoga 2013, 6(2):123-127.

91. Narendran S, Nagarathna R, Gunasheela S, Nagendra HR: Efficacy of yoga in pregnant women with abnormal Doppler study of umbilical and uterine arteries. J Indian Med Assoc 2005, 103(1):12-14. 16-17.

92. Narendran S, Nagarathna R, Narendran V, Gunasheela S, Nagendra HR: Efficacy of yoga on pregnancy outcome. J Altern Complement Med 2005, 11(2):237-244.

93. Naveen GH, Thirthalli J, Rao MG, Varambally S, Christopher R, Gangadhar BN: Positive therapeutic and neurotropic effects of yoga in depression: a comparative study. Indian J Psychiatry 2013, 55(Suppl 3):S400-S404.

94. Oken BS, Flegal K, Zajdel D, Kishiyama SS, Lovera J, Bagert B, Bourdette DN: Cognition and fatigue in multiple sclerosis: potential effects of medications with central nervous system activity. J Rehabil Res Dev 2006, 43(1):83-90

95. Park J, McCaffrey R: Chair yoga: benefits for community-dwelling older adults with osteoarthritis. J Gerontol Nurs 2012, 38(5):12-22.

96. Phoosuwan M, Kritpet T, Yuktanandana P: The effects of weight bearing yoga training on the bone resorption markers of the postmenopausal women. J Med Assoc Thai 2009, 92(Suppl5):S102-S108.

97. Platania-Solazzo A, Field TM, Blank J, Seligman F, Kuhn C, Schanberg S, Saab $P$ : Relaxation therapy reduces anxiety in child and adolescent psychiatric patients. Acta Paedopsychiatr 1992, 55(2):115-120.

98. Sathyaprabha TN, Satishchandra P, Pradhan C, Sinha S, Kaveri B, Thennarasu K, Murthy BT, Raju TR: Modulation of cardiac autonomic balance with adjuvant yoga therapy in patients with refractory epilepsy. Epilepsy Behav 2008, 12(2):245-252

99. Schell FJ, Allolio B, Schonecke OW: Physiological and psychological effects of Hatha-Yoga exercise in healthy women. Int J Psychosom 1994, 41(1-4):46-52.

100. Schulz LH, Uyterhoeven S, Khalsa SB: Evaluation of a yoga program for back pain. J Yoga Phys Ther 2011, 1:e103.

101. Sharma B, Misra R, Singh K, Archana RS: Comparative study of effect of anuloma-viloma (pranayam) and yogic asanas in premenstrual syndrome. Indian J Physiol Pharmacol 2013, 57(4):384-389.

102. Sherman KJ, Wellman RD, Cook AJ, Cherkin DC, Ceballos RM: Mediators of yoga and stretching for chronic low back pain. Evid Based Complement Alternat Med 2013, 2013:130818. 
103. Singh S, Kyizom T, Singh KP, Tandon OP, Madhu SV: Influence of pranayamas and yoga-asanas on serum insulin, blood glucose and lipid profile in type 2 diabetes. Indian J Clin Biochem 2008, 23(4):365-368.

104. Singh S, Malhotra V, Singh KP, Sharma SB, Madhu SV, Tandon OP: A preliminary report on the role of yoga asanas on oxidative stress in non-insulin dependent diabetes mellitus. Indian J Clin Biochem 2001, 16(2):216-220.

105. Smith JA, Greer T, Sheets T, Watson S: Is there more to yoga than exercise? Altern Ther Health Med 2011, 17(3):22-29.

106. Stein KM, Weinberg J, Sherman KJ, Lemaster CM, Saper R: Participant characteristics associated with symptomatic improvement from yoga for chronic Low back pain. J Yoga Phys Ther 2014, 4:151

107. Sun YC, Hung YC, Chang Y, Kuo SC: Effects of a prenatal yoga programme on the discomforts of pregnancy and maternal childbirth self-efficacy in Taiwan. Midwifery 2010, 26(6):e31-e36.

108. Sundar S, Agrawal SK, Singh VP, Bhattacharya SK, Udupa KN, Vaish SK: Role of yoga in management of essential hypertension. Acta Cardiol 1984, 39(3):203-208

109. Telles S, Gaur V, Balkrishna A: Effect of a yoga practice session and a yoga theory session on state anxiety. Percept Mot Skills 2009, 109(3):924-930.

110. Telles S, Maharana K, Balrana B, Balkrishna A: Effects of high-frequency yoga breathing called kapalabhati compared with breath awareness on the degree of optical illusion perceived. Percept Mot Skills 2011, 112(3):981-990.

111. Uthirapathy A: Influence of yogic practices and aerobic exercises on serum protein level. J Exercise Sci Physiother 2007, 3(2):153-156.

112. Vadiraja HS, Rao MR, Nagarathna R, Nagendra HR, Rekha M, Vanitha N, Gopinath KS, Srinath BS, Vishweshwara MS, Madhavi YS, Ajaikumar BS, Bilimagga SR, Rao N: Yoga leads to improved QoL in breast cancer patients receiving radiotherapy. Focus Altern Complement Ther 2010, 15(2):149-150.

113. West J, Otte C, Geher K, Johnson J, Mohr DC: Effects of Hatha yoga and African dance on perceived stress, affect, and salivary cortisol. Ann Behav Med 2004, 28(2):114-118.

114. Wolff M, Sundquist K, Larsson LS, Midlov P: Impact of yoga on blood pressure and quality of life in patients with hypertension - a controlled trial in primary care, matched for systolic blood pressure. BMC CardiovasC Disord 2013, 13:111.

115. Yogendra J, Yogendra HJ, Ambardekar S, Lele RD, Shetty S, Dave M, Husein $N$ : Beneficial effects of yoga lifestyle on reversibility of ischaemic heart disease: caring heart project of International Board of Yoga. J Assoc Physicians India 2004, 52:283-289.

116. Blom K, Baker B, How M, Dai M, Irvine J, Abbey S, Abramson BL, Myers MG, Kiss A, Perkins NJ, Tobe SW: Hypertension analysis of stress reduction using mindfulness meditation and yoga: results from the harmony randomized controlled trial. Am J Hypertens 2014, 27(1):122-129.

117. Cardozo B, Thakar AB, Skandhan KP: A clinical study on psyco-somatic management of shukraavrlta vata (premature ejaculation) with rasayana yoga and shirodhara. Ayu 2006, 27(4):94-98.

118. Carlson LE, Doll R, Stephen J, Faris P, Tamagawa R, Drysdale E, Speca M: Randomized controlled trial of Mindfulness-based cancer recovery versus supportive expressive group therapy for distressed survivors of breast cancer. J Clin Oncol 2013, 31(25):3119-3126.

119. Carlson LE, Speca M, Patel KD, Goodey E: Mindfulness-based stress reduction in relation to quality of life, mood, symptoms of stress and levels of cortisol, dehydroepiandrosterone sulfate (DHEAS) and melatonin in breast and prostate cancer outpatients. Psychoneuroendocrinology 2004, 29(4):448-474.

120. DeBar LL, Stevens VJ, Perrin N, Wu P, Pearson J, Yarborough BJ, Dickerson J, Lynch F: A primary care-based, multicomponent lifestyle intervention for overweight adolescent females. Pediatrics 2012, 129(3):e611-e620.

121. Dhamale M, Bhojani MK, Bhatted S, Dwivedi RR: Understanding and treating uchcha raktachapa (hypertension) in perspective of vidhishonitiya adhyaya of charaka samhita - a clinical review. Ayu 2009, 30(3):284-294.

122. DiPietro L, Seeman TE, Stachenfeld NS, Katz LD, Nadel ER: Moderateintensity aerobic training improves glucose tolerance in aging independent of abdominal adiposity. J Am Geriatr Soc 1998, 46(7):875-879

123. Duru OK, Sarkisian CA, Leng M, Mangione CM: Sisters in motion: a randomized controlled trial of a faith-based physical activity intervention. J Am Geriatr Soc 2010, 58(10):1863-1869.
124. Jatuporn S, Sangwatanaroj S, Saengsiri AO, Rattanapruks S, Srimahachota S, Uthayachalerm W, Kuanoon W, Panpakdee O, Tangkijvanich P, Tosukhowong P: Short-term effects of an intensive lifestyle modification program on lipid peroxidation and antioxidant systems in patients with coronary artery disease. Clin Hemorheol Microcirc 2003, 29(3-4):429-436.

125. Jellesma FC, Cornelis J: Mind magic: a pilot study of preventive mindbody-based stress reduction in behaviorally inhibited and activated children. J Holist Nurs 2012, 30(1):55-62.

126. Khasky AD, Smith JC: Stress, relaxation states, and creativity. Percept Mot Skills 1999, 88(2):409-416.

127. Kligler B, Homel P, Blank AE, Kenney J, Levenson H, Merrell W: Randomized trial of the effect of an integrative medicine approach to the management of asthma in adults on disease-related quality of life and pulmonary function. Altern Ther Health Med 2011, 17(1):10-15.

128. Kulkarni PV, Chandola H: Evaluation of Stambhanakaraka Yoga and counseling in the management of Shukragata Vata (premature ejaculation). Ayu 2013, 34(1):42-48.

129. Matsumoto $M$, Smith JC: Progressive muscle relaxation, breathing exercises, and ABC relaxation theory. J Clin Psychol 2001, 57(12):1551-1557.

130. Ornish D, Lin J, Chan JM, Epel E, Kemp C, Weidner G, Marlin R, Frenda SJ, Magbanua MJM, Daubenmier J, Estay I, Hills NK, Chainani-Wu N, Carroll PR, Blackburn EH: Effect of comprehensive lifestyle changes on telomerase activity and telomere length in men with biopsy-proven low-risk prostate cancer: 5-year follow-up of a descriptive pilot study. Lancet Oncol 2013, 14(11):1112-1120.

131. Pokladnikova J, Selke-Krulichova I: Effectiveness of a comprehensive lifestyle modification program for asthma patients: a randomized controlled pilot trial. J Asthma 2013, 50(3):318-326.

132. Strijk JE, Proper KI, van der Beek AJ, van Mechelen W: A worksite vitality intervention to improve older workers' lifestyle and vitality-related outcomes: results of a randomised controlled trial. J Epidemiol Community Health 2012, 66(11):1071-1078.

133. Strijk JE, Proper Kl, van Mechelen W, van der Beek AJ: Effectiveness of a worksite lifestyle intervention on vitality, work engagement, productivity, and sick leave: results of a randomized controlled trial. Scand J Work Environ Health 2013, 39(1):66-75.

134. van Montfrans GA, Karemaker JM, Wieling W, Dunning AJ: Relaxation therapy and continuous ambulatory blood pressure in mild hypertension: a controlled study. BMJ 1990, 300(6736):1368-1372.

135. Ades PA, Savage PD, Brochu M, Tischler MD, Lee NM, Poehlman ET: Resistance training increases total daily energy expenditure in disabled older women with coronary heart disease. J Appl Physiol (1985) 2005, 98(4):1280-1285.

136. Ades PA, Savage PD, Cress ME, Brochu M, Lee NM, Poehlman ET: Resistance training on physical performance in disabled older female cardiac patients. Med Sci Sports Exerc 2003, 35(8):1265-1270.

137. Afonso RF, Hachul H, Kozasa EH, Oliveira Dde S, Goto V, Rodrigues D, Tufik S, Leite JR: Yoga decreases insomnia in postmenopausal women: a randomized clinical trial. Menopause 2012, 19(2):186-193.

138. Agarwal BB, Sharma S, Gupta MK, Sarangi R, Mahajan KC: Can Yoga improve the outcome of surgery for haemorrhoids? A prospective randomized controlled study. I International Medical Sciences Academy 2012, 25(1):43-46.

139. Agrawal RP, Aradhana HS, Beniwal R, Sabir M, Kochar DK, Kothari RP. Influence of yogic treatment on quality of life outcomes, glycemic control and risk factors in diabetes mellitus. International J Diabetes in Developing Countries 2003, 23(4):130-134.

140. Ahmadi A, Arastoo AA, Nikbakht M, Zahednejad S, Rajabpour M: Comparison of the effect of 8 weeks aerobic and yoga training on ambulatory function, fatigue and mood status in MS patients. Iran Red Crescent Med J 2013, 15(6):449-454.

141. Ahmadi A, Nikbakh M, Arastoo A, Habibi AH: The Effects of a yoga intervention on balance, speed and endurance of walking, fatigue and quality of life in people with multiple sclerosis. J Human Kinetics 2010, 23(1):71-78

142. Amita S, Prabhakar S, Manoj I, Harminder S, Pavan T: Effect of yoga-nidra on blood glucose level in diabetic patients. Indian J Physiol Pharmacol 2009, 53(1):97-101

143. Armstrong WJ, Scott Smedley JM: Effects of a home-based yoga exercise program on flexibility in older women. Clin Kinesiol 2003, 57(1):1-6. 
144. Aslan UB, Livanelioǧlu A: Effects of Hatha Yoga training on aerobic power and anaerobic power in healthy young adults. Fizyoterapi Rehabilitasyon 2002, 13(1):24-30.

145. Attanayake AMP, Somarathna K, Vyas GH, Dash SC: Clinical evaluation of selected yogic procedures in individuals with low back pain. Ayu 2010, 31(2):245-250.

146. Avis NE, Legault C, Russell G, Weaver K, Danhauer SC: Pilot study of integral yoga for menopausal hot flashes. Menopause 2014, 21(8):846-854

147. Bali Y, Ebnezar J: Efficacy of mind sound resonance technique in common neck pain. International J Res Ayurveda and Pharmacy 2012, 3(2):227-232.

148. Banasik J, Williams H, Haberman M, Blank SE, Bendel R: Effect of lyengar yoga practice on fatigue and diurnal salivary cortisol concentration in breast cancer survivors. J Am Acad Nurse Pract 2011, 23(3):135-142.

149. Banerjee B, Vadiraj HS, Ram A, Rao R, Jayapal M, Gopinath KS, Ramesh BS, Rao N, Kumar A, Raghuram N, Hegde S, Nagendra HR, Prakash Hande M: Effects of an integrated yoga program in modulating psychological stress and radiation-induced genotoxic stress in breast cancer patients undergoing radiotherapy. Integr Cancer Ther 2007, 6(3):242-250.

150. Behere RV, Arasappa R, Jagannathan A, Varambally S, Venkatasubramanian G, Thirthalli J, Subbakrishna DK, Nagendra HR, Gangadhar BN: Effect of yoga therapy on facial emotion recognition deficits, symptoms and functioning in patients with schizophrenia. Acta Psychiatr Scand 2011, 123(2):147-153.

151. Bellad AS, Goudar SS: Effect of yoga on motor performance of upper limbs among laboratory workers - Randomized controlled trial. Biomedicine (India) 2012, 32(2):222-227.

152. Bera TK, Rajapurkar MV: Body composition, cardiovascular endurance and anaerobic power of yogic practitioner. Indian J Physiol Pharmacol 1993, 37(3):225-228.

153. Bernardi ML, Amorim MH, Zandonade E, Santaella DF, Barbosa JA: The effects of hatha yoga exercises on stress and anxiety levels in mastectomized women. Cien Saude Colet 2013, 18(12):3621-3632.

154. Bhandari R, Singh VK: A research paper on "effect of yogic package on rheumatoid arthritis". Indian J Biomechanics 2009, Special Issue (NCBM 7-8 March 2009):175-179. Special Issue(National Conference on Biomechanics 2009.

155. Bhandari R, Acharya B, Katiyar VK: Corporate yoga and its implications. IFMBE Proc 2010, 31:290-293.

156. Bhat PS, Chopra V, Mehta SG, Srivastava K, Kumar SR, Prakash J: Psychological benefits of yoga in industrial workers. Ind Psychiatry J 2012, 21(2):98-103.

157. Bhavanani AB, Udupa K, Madanmohan RP: A comparative study of slow and fast suryanamaskar on physiological function. Int J Yoga 2011, 4(2):71-76.

158. Bhende AM, Zade SB, Sitre SR, Wasu YH: Effect of yogic practices on the management of hypertension in working women. International J Biomedical and Healthcare Sci 2011, 1(1):1-7.

159. Bidwell AJ, Yazel B, Davin D, Fairchild TJ, Kanaley JA: Yoga training improves quality of life in women with asthma. J Altern Complement Med 2012, 18(8):749-755

160. Bilderbeck AC, Farias M, Brazil IA, Jakobowitz S, Wikholm C: Participation in a 10-week course of yoga improves behavioural control and decreases psychological distress in a prison population. J Psychiatr Res 2013, 47(10):1438-1445

161. Biswas D, Yeola M, Naik A: A study of Rajyoga meditation on quality of life of patients with fibroadenosis. J Datta Meghe Institute of Medical Sciences University 2012, 7(4):247-252.

162. Black DS, Cole SW, Irwin MR, Breen E, St Cyr NM, Nazarian N, Khalsa DS, Lavretsky $\mathrm{H}$ : Yogic meditation reverses NF-kappaB and IRF-related transcriptome dynamics in leukocytes of family dementia caregivers in a randomized controlled trial. Psychoneuroendocrinology 2012, 38(3):348-355.

163. Blank SE, Kittel J, Haberman MR: Active practice of lyengar yoga as an intervention for breast cancer survivors. Int J Yoga Ther 2003, 13:51-59.

164. Blumenthal JA, Emery CF, Madden DJ, Coleman RE, Riddle MW, Schniebolk S, Cobb FR, Sullivan MJ, Higginbotham MB: Effects of exercise training on cardiorespiratory function in men and women older than 60 years of age. Am J Cardiol 1991, 67(7):633-639.

165. Blumenthal JA, Emery CF, Madden DJ, George LK, Coleman RE, Riddle MW McKee DC, Reasoner J, Williams RS: Cardiovascular and behavioral effects of aerobic exercise training in healthy older men and women. $J$ Gerontol 1989, 44(5):M147-M157.
166. Blumenthal JA, Emery CF, Madden DJ, Schniebolk S, Riddle MW, Cobb FR, Higginbotham M, Coleman RE: Effects of exercise training on bone density in older men and women. J Am Geriatr Soc 1991, 39(11):1065-1070.

167. Blumenthal JA, Emery CF, Madden DJ, Schniebolk S, Walsh-Riddle M, George LK, McKee DC, Higginbotham MB, Cobb FR, Coleman RE: Long-term effects of exercise on psychological functioning in older men and women. J Gerontol 1991, 46(6):352-361.

168. Bock BC, Fava JL, Gaskins R, Morrow KM, Williams DM, Jennings E, Becker BM, Tremont G, Marcus BH: Yoga as a complementary treatment for smoking cessation in women. J Womens Health (Larchmt) 2012, 21(2):240-248.

169. Bonura KB, Tenenbaum G: Effects of yoga on psychological health in older adults. J Phys Act Health 2013

170. Bowden D, Gaudry C, An SC, Gruzelier J: A comparative randomised controlled trial of the effects of brain wave vibration training, iyengar yoga, and mindfulness on mood, well-being, and salivary cortisol. Evid Based Complement Alternat Med 2012, 2012:234713.

171. Bower JE, Garet D, Sternlieb B, Ganz PA, Irwin MR, Olmstead R, Greendale G: Yoga for persistent fatigue in breast cancer survivors: a randomized controlled trial. Cancer 2012, 118(15):3766-3775

172. Bowman AJ, Clayton RH, Murray A, Reed JW, Subhan MM, Ford GA: Effects of aerobic exercise training and yoga on the baroreflex in healthy elderly persons. Eur J Clin Invest 1997, 27(5):443-449.

173. Brazier A, Mulkins A, Verhoef M: Evaluating a yogic breathing and meditation intervention for individuals living with HIV/AIDS. Am J Health Promot 2006, 20(3):192-195.

174. Broota A, Dhir R: Eficacy of two relaxation techniques in depression. J Personal Clin Stud 1990, 6(1):83-90

175. Bryan S, Pinto Zipp G, Parasher R: The effects of yoga on psychosocial variables and exercise adherence: a randomized, controlled pilot study. Altern Ther Health Med 2012, 18(5):50-59.

176. Butler LD, Waelde LC, Hastings TA, Chen XH, Symons B, Marshall J, Kaufman A, Nagy TF, Blasey CM, Seibert EO, Spiegel D: Meditation with yoga, group therapy with hypnosis, and psychoeducation for long-term depressed mood: a randomized pilot trial. J Clin Psychol 2008, 64(7):806-820.

177. Cade WT, Reeds DN, Mondy KE, Overton ET, Grassino J, Tucker S, Bopp C, Laciny E, Hubert S, Lassa-Claxton S, Yarasheski KE: Yoga lifestyle intervention reduces blood pressure in HIV-infected adults with cardiovascular disease risk factors. HIV Med 2010, 11(6):379-388.

178. Carei TR, Fyfe-Johnson AL, Breuner CC, Brown MA: Randomized controlled clinical trial of yoga in the treatment of eating disorders. $J$ Adolesc Health 2010, 46(4):346-351.

179. Carson JW, Carson KM, Jones KD, Bennett RM, Wright CL, Mist SD: A pilot randomized controlled trial of the Yoga of Awareness program in the management of fibromyalgia. Pain 2010, 151(2):530-539.

180. Carson JW, Carson KM, Porter LS, Keefe FJ, Seewaldt VL: Yoga of Awareness program for menopausal symptoms in breast cancer survivors: results from a randomized trial. Support Care Cancer 2009, 17(10):1301-1309.

181. Carter JJ, Gerbag PL, Brown RP, Ware RS, D'Ambrosio C, Anand L, Dirlea M, Vermani M, Katzman MA: Multi-component yoga breath program for Vietnam veteran post traumatic stress disorder: randomized controlled trial. J Traumat Stress Disord Treat 2013, 2(3):57-65.

182. Cebria IIMD, Arnall DA, Igual Camacho C, Tomas JM: Effects of inspiratory muscle training and yoga breathing exercises on respiratory muscle function in institutionalized frail older adults: a randomized controlled trial. J Geriatr Phys Ther 2013, 37(2):65-75.

183. Chan W, Immink MA, Hillier S: Yoga and exercise for symptoms of depression and anxiety in people with poststroke disability: a randomized, controlled pilot trial. Altern Ther Health Med 2012, 18(3):34-43.

184. Chandwani KD, Thornton B, Perkins GH, Arun B, Raghuram NV, Nagendra $H R$, Wei Q, Cohen L: Yoga improves quality of life and benefit finding in women undergoing radiotherapy for breast cancer. J Soc Integr Oncol 2010, 8(2):43-55

185. Chattha R, Nagarathna R, Padmalatha V, Nagendra HR: Effect of yoga on cognitive functions in climacteric syndrome: a randomised control study. BJOG 2008, 115(8):991-1000.

186. Chattha R, Raghuram N, Venkatram P, Hongasandra NR: Treating the climacteric symptoms in Indian women with an integrated approach to yoga therapy: a randomized control study. Menopause 2008, 15(5):862-870 
187. Chaya MS, Nagendra H, Selvam S, Kurpad A, Srinivasan K: Effect of yoga on cognitive abilities in schoolchildren from a socioeconomically disadvantaged background: a randomized controlled study. J Altern Complement Med 2012, 18(12):1161-1167.

188. Cheema BS, Houridis A, Busch L, Raschke-Cheema V, Melville GW, Marshall PW, Chang D, Machliss B, Lonsdale C, Bowman J, Colagiuri B: Effect of an office worksite-based yoga program on heart rate variability: outcomes of a randomized controlled trial. BMC Complement Altern Med 2013, 13:82.

189. Chen KM, Chen MH, Chao HC, Hung HM, Lin HS, Li CH: Sleep quality, depression state, and health status of older adults after silver yoga exercises: cluster randomized trial. Int J Nurs Stud 2009, 46(2):154-163.

190. Chen KM, Chen MH, Hong SM, Chao HC, Lin HS, Li CH: Physical fitness of older adults in senior activity centres after 24-week silver yoga exercises. J Clin Nurs 2008, 17(19):2634-2646.

191. Chen KM, Chen MH, Lin MH, Fan JT, Lin HS, Li CH: Effects of yoga on sleep quality and depression in elders in assisted living facilities. J Nurs Res 2010, 18(1):53-61.

192. Chen KM, Fan JT, Wang HH, Wu SJ, Li CH, Lin HS: Silver yoga exercises improved physical fitness of transitional frail elders. Nurs Res 2010, 59(5):364-370.

193. Choudhary A, Mishra J: Effect of 16 weeks yogic intervention in premenstrual syndrome. International J Pharma and Bio Sci 2013, 4(1):B207-b212.

194. Choudhary R, Kulmatycki L, Meena TR: Trend of the effects of four varieties of yoga Bhastrika Pranayama on physical efficiency index. Archives of Budo 2012, 8(2):117-124.

195. Chuntharapat S, Petpichetchian W, Hatthakit U: Yoga during pregnancy: effects on maternal comfort, labor pain and birth outcomes. Complement Ther Clin Pract 2008, 14(2):105-115.

196. Clark PG, Cortese-Jimenez G, Cohen E: Effects of Reiki, yoga, or meditation on the physical and psychological symptoms of chemotherapy-induced peripheral neuropathy: a randomized pilot study. J Evidence-Based Complement Alternat Med 2012, 17(3):161-171.

197. Cohen BE, Chang AA, Grady D, Kanaya AM: Restorative yoga in adults with metabolic syndrome: a randomized, controlled pilot trial. Metab Syndr Relat Disord 2008, 6(3):223-229.

198. Cohen DL, Bloedon LT, Rothman RL, Farrar JT, Galantino ML, Volger S, Mayor C, Szapary PO, Townsend RR: lyengar yoga versus enhanced usual care on blood pressure in patients with prehypertension to stage I hypertension: a randomized controlled trial. Evid Based Complement Alternat Med 2011, 2011:546428.

199. Cohen L, Warneke C, Fouladi RT, Rodriguez MA, Chaoul-Reich A: Psychological adjustment and sleep quality in a randomized trial of the effects of a Tibetan yoga intervention in patients with lymphoma. Cancer 2004, 100(10):2253-2260

200. Colgrove YS: Effect of yoga on motor function in people with Parkinson's disease: a randomized, controlled pilot study. J Yoga Phys Ther 2012, 2(2):112.

201. Cooper S, Oborne J, Newton S, Harrison V, Thompson Coon J, Lewis S, Tattersfield A: Effect of two breathing exercises (Buteyko and pranayama) in asthma: a randomised controlled trial. Thorax 2003, 58(8):674-679.

202. Cox H, Tilbrook H, Aplin J, Semlyen A, Torgerson D, Trewhela A, Watt I: A randomised controlled trial of yoga for the treatment of chronic low back pain: results of a pilot study. Complement Ther Clin Pract 2010, 16(4):187-193.

203. Cramer H, Lauche R, Hohmann C, Ludtke R, Haller H, Michalsen A, Langhorst J, Dobos G: Randomized-controlled trial comparing yoga and homebased exercise for chronic neck pain. Clin J Pain 2013, 29(3):216-223.

204. Culos-Reed SN, Carlson LE, Daroux LM, Hately-Aldous S: A pilot study of yoga for breast cancer survivors: physical and psychological benefits. Psychooncology 2006, 15(10):891-897.

205. Culos-Reed SN ECL, Daroux LM, Hately-Aldous S: Discovering the physical and psychological benefits of yoga for cancer survivors. Int I Yoga Therap 2004, 14:45-52.

206. Cusumano JA, Robinson SE: The short-term psychophysiological effects of hatha yoga and progressive relaxation on female Japanese students. Appl Psychol 1992, 42:77-90.

207. da Silva GD, Lorenzi-Filho G, Lage LV: Effects of yoga and the addition of Tui $\mathrm{Na}$ in patients with fibromyalgia. J Altern Complement Med 2007, 13(10):1107-1113.

208. Danhauer SC, Mihalko SL, Russell GB, Campbell CR, Felder L, Daley K, Levine EA: Restorative yoga for women with breast cancer: findings from a randomized pilot study. Psychooncology 2009, 18(4):360-368.
209. Deshpande C, Rakshani A, Nagarathna R, Ganpat T, Kurpad A, Maskar R, Nagendra H, Sudheer D, Abbas R, Raghuram N, Anura K, Rita M, Ramarao N: Yoga for high-risk pregnancy: a randomized controlled trial. Ann Med Health Sci Res 2013, 3(3):341-344.

210. Deshpande S, Nagendra HR, Raghuram N: A randomized control trial of the effect of yoga on gunas (personality) and health in normal healthy volunteers. Int J Yoga 2008, 1(1):2-10.

211. Deshpande S, Nagendra HR, Raghuram N: A randomized control trial of the effect of yoga on verbal aggressiveness in normal healthy volunteers. Int J Yoga 2008, 1(2):76-82.

212. Deshpande S, Nagendra HR, Raghuram N: A randomized control trial of the effect of yoga on gunas (personality) and self esteem in normal healthy volunteers. Int J Yoga 2009, 2(1):13-21.

213. Dhruva A, Miaskowski C, Abrams D, Acree M, Cooper B, Goodman S, Hecht FM: Yoga breathing for cancer chemotherapy-associated symptoms and quality of life: results of a pilot randomized controlled trial. $J$ Altern Complement Med 2012, 18(5):473-479.

214. Donesky-Cuenco D, Nguyen HQ, Paul S, Carrieri-Kohlman V: Yoga therapy decreases dyspnea-related distress and improves functional performance in people with chronic obstructive pulmonary disease: a pilot study. J Altern Complement Med 2009, 15(3):225-234.

215. Donohue B, Miller A, Beisecker M, Houser D, Valdez R, Tiller S, Taymar T: Effects of brief yoga exercises and motivational preparatory interventions in distance runners: results of a controlled trial. $\mathrm{Br} J$ Sports Med 2006, 40(1):60-63.

216. Doulatabad SN, Nooreyan K, Doulatabad AN, Noubandegani ZM: The effects of pranayama, hatha and raja yoga on physical pain and the quality of life of women with multiple sclerosis. Afr J Tradit Complement Altern Med 2012, 10(1):49-52.

217. Duraiswamy G, Thirthalli J, Nagendra HR, Gangadhar BN: Yoga therapy as an add-on treatment in the management of patients with schizophrenia-a randomized controlled trial. Acta Psychiatr Scand 2007, 116(3):226-232.

218. Ebnezar J, Nagarathna R, Bali Y, Nagendra HR: Effect of an integrated approach of yoga therapy on quality of life in osteoarthritis of the knee joint: a randomized control study. Int J Yoga 2011, 4(2):55-63.

219. Ebnezar J, Nagarathna R, Yogitha B, Nagendra HR: Effects of an integrated approach of hatha yoga therapy on functional disability, pain, and flexibility in osteoarthritis of the knee joint: a randomized controlled study. J Altern Complement Med 2012, 18(5):463-472.

220. Ebnezar J, Nagarathna R, Yogitha B, Nagendra HR: Effect of integrated yoga therapy on pain, morning stiffness and anxiety in osteoarthritis of the knee joint: a randomized control study. Int J Yoga 2012, 5(1):28-36.

221. Ebnezar J, Yogitha B: Effectiveness of yoga therapy with the therapeutic exercises on walking pain, tenderness. Early morning stiffness and disability in osteoarthritis of the knee joint - a comparative study. Yoga \& Physical Therapy 2012, 2:114.

222. Elavsky S, McAuley E: Exercise and self-esteem in menopausal women: a randomized controlled trial involving walking and yoga. Am J Health Promot 2007, 22(2):83-92.

223. Elavsky S, McAuley E: Physical activity and mental health outcomes during menopause: a randomized controlled trial. Ann Behav Med 2007, 33(2):132-142.

224. Elibero A, Janse Van Rensburg K, Drobes DJ: Acute effects of aerobic exercise and Hatha yoga on craving to smoke. Nicotine Tob Res 2011, 13(11):1140-1148.

225. Emery CF, Blumenthal JA: Perceived change among participants in an exercise program for older adults. Gerontologist 1990, 30(4):516-521.

226. Evans S, Moieni M, Lung K, Tsao J, Sternlieb B, Taylor M, Zeltzer L: Impact of iyengar yoga on quality of life in young women with rheumatoid arthritis. Clin J Pain 2013, 29(11):988-997.

227. Field T, Diego M, Delgado J, Medina L: Yoga and social support reduce prenatal depression. Anxiety and cortisol. J Yoga Phys Ther 2012, 2:124

228. Field T, Diego M, Delgado J, Medina L: Yoga and social support reduce prenatal depression, anxiety and cortisol. J Bodyw Mov Ther 2013, 17(4):397-403.

229. Field T, Diego M, Delgado J, Medina L: Tai chi/yoga reduces prenatal depression, anxiety and sleep disturbances. Complement Ther Clin Pract 2013, 19(1):6-10.

230. Field T, Diego M, Hernandez-Reif M, Medina L, Delgado J, Hernandez A: Yoga and massage therapy reduce prenatal depression and prematurity. J Bodyw Mov Ther 2012, 16(2):204-209. 
231. Fluge T, Richter J, Fabel H, Zysno E, Weller E, Wagner TOF: Long-term effects of breathing exercises and yoga in patients suffering from bronchial asthma. Pneumologie 1994, 48(7):484-490.

232. Franzblau SH, Echevarria S, Smith M, Van Cantfort TE: A preliminary investigation of the effects of giving testimony and learning yogic breathing techniques on battered women's feelings of depression. $J$ Interpers Violence 2008, 23(12):1800-1808.

233. Galantino ML, Bzdewka TM, Eissler-Russo JL, Holbrook ML, Mogck EP, Geigle $P$, Farrar JT: The impact of modified Hatha yoga on chronic low back pain: a pilot study. Altern Ther Health Med 2004, 10(2):56-59.

234. Gangadhar BN, Naveen GH, Rao MG, Thirthalli J, Varambally S: Positive antidepressant effects of generic yoga in depressive out-patients: A comparative study. Indian J Psychiatry 2013, 55(Suppl 3):S369-S373.

235. Garfinkel MS, Schumacher HR Jr, Husain A, Levy M, Reshetar RA: Evaluation of a yoga based regimen for treatment of osteoarthritis of the hands. J Rheumatol 1994, 21(12):2341-2343.

236. Garfinkel MS, Singhal A, Katz WA, Allan DA, Reshetar R, Schumacher HR: Yoga-based intervention for carpal tunnel syndrome: a randomized trial. JAMA 1998, 280(18):1601-1603.

237. Garrett M, Hogan N, Larkin A, Saunders J, Jakeman P, Coote S: Exercise in the community for people with minimal gait impairment due to MS: an assessor-blind randomized controlled trial. Mult Scler 2013, 19(6):782-789.

238. Ghoncheh S, Smith JC: Progressive muscle relaxation, yoga stretching, and ABC relaxation theory. J Clin Psychol 2004, 60(1):131-136.

239. Gopal A, Mondal S, Gandhi A, Arora S, Bhattacharjee J: Effect of integrated yoga practices on immune responses in examination stress - a preliminary study. Int J Yoga 2011, 4(1):26-32.

240. Gopinathan G, Dhiman KS, Manjusha R: A clinical study to evaluate the efficacy of Trataka Yoga Kriya and eye exercises (non-pharmocological methods) in the management of Timira (Ammetropia and Presbyopia). Ayu 2012, 33(4):543-546.

241. Gordon L, McGrowder DA, Pena YT, Cabrera E, Lawrence-Wright M: Effect of exercise therapy on lipid parameters in patients with end-stage renal disease on hemodialysis. J Lab Physicians 2012, 4(1):17-23.

242. Gordon L, McGrowder DA, Pena YT, Cabrera E, Lawrence-Wright MB: Effect of yoga exercise therapy on oxidative stress indicators with end-stage renal disease on hemodialysis. Int J Yoga 2013, 6(1):31-38.

243. Gordon L, Morrison EY, McGrowder D, Penas YF, Zamoraz EM, Garwood D, Alexander-Lindo R, Irving R: Effect of yoga and traditional physical exercise on hormones and percentage insulin binding receptor in patients with type 2 diabetes. Am J Biochem Biotechnol 2008, 4(1):35-42.

244. Gordon L, Morrison EY, McGrowder DA, Young R, Garwood D, Zamora E, Alexander-Lindo RL, Irving R, Perez Sanz EC: Changes in clinical and metabolic parameters after exercise therapy in patents with type 2 diabetes. Arch Med Sci 2008, 4(4):427-437.

245. Gordon LA, Morrison EY, McGrowder DA, Young R, Fraser YT, Zamora EM, Alexander-Lindo RL, Irving RR: Effect of exercise therapy on lipid profile and oxidative stress indicators in patients with type 2 diabetes. BMC Complement Altern Med 2008, 8:21.

246. Göring A, Möllenbeck D, Schwarz G: The influence of dynamic yoga styles on spinal flexibility. Zum einfuss dynamischer yogaformen auf die wirbelsäulenbeweglichkeit 2013, 64(9):280-283.

247. Gosewade NB, Shende VS, Kashalikar SJ: Effect of various Eye exercise techniques along with pranayama on visual reaction time: a case control study. J Clin Diagn Res 2013, 7(9):1870-1873

248. Gould LF, Dariotis JK, Mendelson T, Greenberg MT: A school-based mindfulness intervention for urban youth: Exploring moderators of intervention effects. J Community Psychol 2012, 40(8):968-982.

249. Granath J, Ingvarsson S, von Thiele U, Lundberg U: Stress management: a randomized study of cognitive behavioural therapy and yoga. Cogn Behav Ther 2006, 35(1):3-10.

250. Greendale GA, Huang MH, Karlamangla AS, Seeger L, Crawford S: Yoga decreases kyphosis in senior women and men with adult-onset hyperkyphosis: results of a randomized controlled trial. J Am Geriatr Soc 2009, 57(9):1569-1579.

251. Gupta SS, Sawane MV: A comparative study of the effects of yoga and swimming on pulmonary functions in sedentary subjects. Int I Yoga 2012, 5(2):128-133

252. Haber D: Yoga as a preventive health care program for white and black elders: an exploratory study. Int J Aging Hum Dev 1983, 17(3):169-176.
253. Haffner J, Roos J, Goldstein N, Parzer P, Resch F: The effectiveness of body-oriented methods of therapy in the treatment of attention-deficit hyperactivity disorder (ADHD): results of a controlled pilot study. Z Kinder Jugendpsychiatr Psychother 2006, 34(1):37-47

254. Hagins M, Haden SC, Daly LA: A randomized controlled trial on the effects of yoga on stress reactivity in 6th grade students. Evid Based Complement Alternat Med 2013, 2013:607134.

255. Hagins M, Rundle A, Consedine NS, Khalsa SB: A randomized controlled trial comparing the effects of yoga with an active control on ambulatory blood pressure in individuals with prehypertension and stage 1 hypertension. J Clin Hypertens (Greenwich) 2014, 16(1):54-62.

256. Harbans S, Anjali S, Smita J: Comparative clinical evaluation of the antidyslipidaemic effects of lashunadi compound and yogic exercises in patients of metabolic syndrome. Indian J Tradit Knowl 2011, 10(4):651-656.

257. Hari Krishna B, Pal P, Pal GK, Balachander J, Jayasettiaseelon E, Sreekanth Y, Sridhar MG, Gaur GS: Effect of yoga therapy on heart rate, blood pressure and cardiac autonomic function in heart failure. $J$ Clin Diagnostic Res 2014, 8(1):14-16

258. Harinath K, Malhotra AS, Pal K, Prasad R, Kumar R, Kain TC, Rai L, Sawhney RC: Effects of Hatha yoga and Omkar meditation on cardiorespiratory performance, psychologic profile, and melatonin secretion. J Altern Complement Med 2004, 10(2):261-268.

259. Hariprasad VR, Koparde V, Sivakumar PT, Varambally S, Thirthalli J, Varghese M, Basavaraddi IV, Gangadhar BN: Randomized clinical trial of yoga-based intervention in residents from elderly homes: Effects on cognitive function. Indian J Psychiatry 2013, 55(Suppl 3):S357-S363.

260. Hariprasad VR, Sivakumar PT, Koparde V, Varambally S, Thirthalli J, Varghese M, Basavaraddi IV, Gangadhar BN: Effects of yoga intervention on sleep and quality-of-life in elderly: A randomized controlled trial. Indian J Psychiatry 2013, 55(Suppl 3):S364-S368.

261. Hart CE, Tracy BL: Yoga as steadiness training: effects on motor variability in young adults. J Strength Cond Res 2008, 22(5):1659-1669.

262. Hartfiel N, Burton C, Rycroft-Malone J, Clarke G, Havenhand J, Khalsa SB, Edwards RT: Yoga for reducing perceived stress and back pain at work. Occup Med (Lond) 2012, 62(8):606-612.

263. Hartfiel N, Havenhand J, Khalsa SB, Clarke G, Krayer A: The effectiveness of yoga for the improvement of well-being and resilience to stress in the workplace. Scand J Work Environ Health 2011, 37(1):70-76.

264. Hegde SV, Adhikari P, Shetty S, Manjrekar P, D'Souza V: Effect of community-based yoga intervention on oxidative stress and glycemic parameters in prediabetes: a randomized controlled trial. Complement Ther Med 2013, 21(6):571-576.

265. Hogan N, Kehoe M, Larkin A, Coote S: The effect of community exercise interventions for people with MS Who Use bilateral support for gait. Mult Scler Int 2014, 2014:109142.

266. Hovsepian V, Marandi SM, Kelishadi R, Zahed A: A comparison between yoga and aerobic training effects on pulmonary function tests and physical fitness parameters. Pakistan J Med Sci 2013, 29(1 SUPPL.):317-320.

267. Huang FJ, Chien DK, Chung UL: Effects of Hatha yoga on stress in middle-aged women. J Nurs Res 2013, 21(1):59-66.

268. Ide MR, Laurindo IMM, Rodrigues-Junior AL, Tanaka C: Effect of aquatic respiratory exercise-based program in patients with fibromyalgia. Int J Rheum Dis 2008, 11:131-140.

269. Ikai S, Uchida H, Suzuki T, Tsunoda K, Mimura M, Fujii Y: Effects of yoga therapy on postural stability in patients with schizophrenia-spectrum disorders: a single-blind randomized controlled trial. J Psychiatr Res 2013, 47(11):1744-1750.

270. Innes KE, Selfe TK: The effects of a gentle yoga program on sleep, mood, and blood pressure in older women with Restless Legs Syndrome (RLS): a preliminary randomized controlled trial. Evid Based Complement Alternat Med 2012, 2012:294058.

271. Innes KE, Selfe TK, Alexander GK, Taylor AG: A new educational film control for use in studies of active mind-body therapies: acceptability and feasibility. J Altern Complement Med 2011, 17(5):453-458.

272. Janakiramaiah N, Gangadhar BN, Naga Venkatesha Murthy PJ, Harish MG, Subbakrishna DK, Vedamurthachar A: Antidepressant efficacy of Sudarshan Kriya Yoga (SKY) in melancholia: a randomized comparison with electroconvulsive therapy (ECT) and imipramine. J Affect Disord 2000, 57(1-3):255-259.

273. Javadekar P, Manjunath NK: Effect of Surya namaskar on sustained attention in school children. J Yoga Phys Ther 2012, 2:110. 
274. Javnbakht M, Hejazi Kenari R, Ghasemi M: Effects of yoga on depression and anxiety of women. Complement Ther Clin Pract 2009, 15(2):102-104.

275. Jayaram N, Varambally S, Behere RV, Venkatasubramanian G, Arasappa R, Christopher R, Gangadhar BN: Effect of yoga therapy on plasma oxytocin and facial emotion recognition deficits in patients of schizophrenia. Indian J Psychiatry 2013, 55(Suppl 3):S409-S413.

276. Jayashree R, Malini A, Rakhshani A, Nagendra H, Gunasheela S, Nagarathna $R$ : Effect of the integrated approach of yoga therapy on platelet count and uric acid in pregnancy: a multicenter stratified randomized single-blind study. Int J Yoga 2013, 6(1):39-46.

277. Jensen PS, Kenny DT: The effects of yoga on the attention and behavior of boys with Attention-Deficit/hyperactivity Disorder (ADHD). J Atten Disord 2004, 7(4):205-216.

278. John PJ, Sharma N, Sharma CM, Kankane A: Effectiveness of yoga therapy in the treatment of migraine without aura: a randomized controlled trial. Headache 2007, 47(5):654-661.

279. Joshi M, Telles S: Immediate effects of right and left nostril breathing on verbal and spatial scores. Indian J Physiol Pharmacol 2008, 52(2):197-200.

280. Joshi S, Khandwe R, Bapat D, Deshmukh U: Effect of yoga on menopausal symptoms. Menopause Int 2011, 17(3):78-81.

281. Joshi VS, Bellad AS: Effect of yogic exercises on symptoms of musculoskeletal disorders of upper limbs among computer users: a randomised controlled trial. Indian J Med Sci 2011, 65(10):424-428.

282. Jyotsna VP, Ambekar S, Singla R, Joshi A, Dhawan A, Kumar N, Deepak KK, Sreenivas $V$ : Cardiac autonomic function in patients with diabetes improves with practice of comprehensive yogic breathing program. Indian J Endocrinol Metab 2013, 17(3):480-485.

283. Jyotsna VP, Joshi A, Ambekar S, Kumar N, Dhawan A, Sreenivas V: Comprehensive yogic breathing program improves quality of life in patients with diabetes. Indian J Endocrinol Metab 2012, 16(3):423-428.

284. Kanaya AM, Araneta MR, Pawlowsky SB, Barrett-Connor E, Grady D, Vittinghoff E, Schembri M, Chang A, Carrion-Petersen ML, Coggins T, Tanori D, Armas JM, Cole RJ: Restorative yoga and metabolic risk factors: The Practicing Restorative Yoga vs. Stretching for the Metabolic Syndrome (PRYSMS) randomized trial. J Diabetes Complications 2013, 28(3):406-412.

285. Kannappan R, Lakshmi Bai R: Efficacy of yoga: cognitive and human relationship training for correcting maladjustment behaviour in deviant school boys. J Indian Academy of Applied Psychology 2008.

286. Kanojia S, Kumar Sharma V, Gandhi A, Kapoor R, Kukreja A, Kumar Subramanian S: Effect of yoga on autonomic functions and psychological status during both phases of menstrual cycle in young healthy females. J Clinical and Diagnostic Res 2013, 7(10):2133-2139.

287. Katiyar SK, Bihari S: Role of pranayama in the rehabilitation of COPD patients - a randomized controlled study. Indian J Allergy and App/ mmun 2006, 20(2):98-104.

288. Kerr D, Gillam E, Ryder J, Trowbridge S, Cavan D, Thomas P: An eastern art form for a western disease: randomised controlled trial of yoga in patients with poorly controlled insulin-treated diabetes. Practical Diabetes International 2002, 19(6):164-166.

289. Khalsa SB, Shorter SM, Cope S, Wyshak G, Sklar E: Yoga ameliorates performance anxiety and mood disturbance in young professional musicians. Appl Psychophysiol Biofeedback 2009, 34(4):279-289.

290. Khalsa SBS, Hickey-Schultz L, Cohen D, Steiner N, Cope S: Evaluation of the mental health benefits of yoga in a secondary school: A preliminary randomized controlled trial. J Behav Health Serv Res 2012, 39(1):80-90.

291. Khatri D, Mathur KC, Gahlot S, Jain S, Agrawal RP: Effects of yoga and meditation on clinical and biochemical parameters of metabolic syndrome. Diabetes Res Clin Pract 2007, 78(3):e9-e10.

292. Khumar SS, Kaur P, Kaur S: Effectiveness of shavasana on depression among university students. Indian J Clin Psychol 1993, 20(2):82-87.

293. Kim HN, Ryu J, Kim KS, Song SW: Effects of yoga on sexual function in women with metabolic syndrome: a randomized controlled trial. J Sex Med 2013, 10(11):2741-2751.

294. Kim S, Bemben MG, Bemben DA: Effects of an 8-month yoga intervention on arterial compliance and muscle strength in premenopausal women. J Sports Sci Med 2012, 11(2):322-330.

295. Kinser PA, Bourguignon C, Whaley D, Hauenstein E, Taylor AG: Feasibility, acceptability, and effects of gentle hatha yoga for women with major depression: findings from a randomized controlled mixed-methods study. Arch Psychiatr Nurs 2013, 27(3):137-147.
296. Köhn M, Persson Lundholm U, Bryngelsson IL, Anderzén-Carlsson A, Westerdahl E: Medical yoga for patients with stress-related symptoms and diagnoses in primary health care: a randomized controlled trial. Evid Based Complement Alternat Med 2013, 2013:215348.

297. Kovacic T, Kovacic M: Impact of relaxation training according to Yoga In Daily Life(R) system on self-esteem after breast cancer surgery. J Altern Complement Med 2011, 17(12):1157-1164.

298. Kovacic T, Kovacic M: Impact of relaxation training according to Yoga In Daily Life(R) system on perceived stress after breast cancer surgery. Integr Cancer Ther 2011, 10(1):16-26.

299. Kovacic T, Zagoricnik M, Kovacic M: Impact of relaxation training according to the Yoga In Daily Life(R) system on anxiety after breast cancer surgery. J Complement Integr Med 2013, 10(1):153-164.

300. Kozasa EH, Santos RF, Rueda AD, Benedito-Silva AA, De Ornellas FL, Leite JR: Evaluation of Siddha Samadhi Yoga for anxiety and depression symptoms: a preliminary study. Psychol Rep 2008, 103(1):271-274.

301. Krishnamurthy M, Telles S: Effects of Yoga and an Ayurveda preparation on gait, balance and mobility in older persons. Med Sci Monit 2007, 13(12):LE19-LE20.

302. Kröner-Herwig B, Hebing G, Van Rijn-Kalkmann U, Frenzel A, Schilkowsky G, Esser $\mathrm{G}$ : The management of chronic tinnitus - Comparison of a cognitive-behavioural group training with yoga. J Psychosom Res 1995, 39(2):153-165.

303. Kulmatycki L: Yoga and progressive relaxation for anxiety and tension reduction. SENSE 2012, 2(2):93-102.

304. Kulmatycki L, Burzyński Z: Yoga nidra and Benson's meditative relaxation and anxiety level, anger and depression emotions. Postepy Rehabilitacji 2007, 21(3):23-28.

305. Kumar N, Bhatnagar S, Velpandian T, Patnaik S, Menon G, Mehta M, Kashyap K, Surajpal SV: Randomized controlled trial in advance stage breast cancer patients for the effectiveness on stress marker and pain through Sudarshan Kriya and Pranayam. Indian J Palliative Care 2013, 19(3):180-185.

306. Kuttner L, Chambers CT, Hardial J, Israel DM, Jacobson K, Evans K: A randomized trial of yoga for adolescents with irritable bowel syndrome. Pain Res Manag 2006, 11(4):217-223.

307. Latha E, Kaliappan KV: Yoga, pranayama and thermal biofeedback techniques in the mangement of stress and high blood pressure. J Ind Psych 1991, 9:36-46.

308. Lavretsky H, Epel ES, Siddarth P, Nazarian N, Cyr NS, Khalsa DS, Lin J, Blackburn E, Irwin MR: A pilot study of yogic meditation for family dementia caregivers with depressive symptoms: effects on mental health, cognition, and telomerase activity. Int J Geriatr Psychiatry 2013, 28(1):57-65.

309. Lee JA, Kim JW, Kim DY: Effects of yoga exercise on serum adiponectin and metabolic syndrome factors in obese postmenopausal women. Menopause 2012, 19(3):296-301.

310. Littman AJ, Bertram LC, Ceballos R, Ulrich CM, Ramaprasad J, McGregor B, McTiernan A: Randomized controlled pilot trial of yoga in overweight and obese breast cancer survivors: effects on quality of life and anthropometric measures. Support Care Cancer 2012, 20(2):267-277.

311. Lu C, Wang B: A study on effects of aerobics combined with yoga exercise on physical training. Chinese J Rehabil Med 2007, 22(10):885-887.

312. Lundgren T, Dahl J, Yardi N, Melin L: Acceptance and commitment therapy and yoga for drug-refractory epilepsy: a randomized controlled trial. Epilepsy Behav 2008, 13(1):102-108.

313. Madden DJ, Blumenthal JA, Allen PA, Emery CF: Improving aerobic capacity in healthy older adults does not necessarily lead to improved cognitive performance. Psychol Aging 1989, 4(3):307-320.

314. Mahajan AS, Reddy KS, Sachdeva U: Lipid profile of coronary risk subjects following yogic lifestyle intervention. Indian Heart J 1999, 51(1):37-40.

315. Malathi A, Damodaran A: Stress due to exams in medical students-role of yoga. Indian J Physiol Pharmacol 1999, 43(2):218-224.

316. Malathi A, Damodaran A, Shah N, Krishnamurthy G, Namjoshi P, Ghodke S: Psychophysiological changes at the time of examination in medical students before and after the practice of yoga and relaxation. Indian J Psychiatry 1998, 40(1):35-40.

317. Mamidi P, Gupta K: Efficacy of certain yogic and naturopathic procedures in premature ejaculation: a pilot study. Int J Yoga 2013, 6(2):118-122.

318. Manchanda SC: Reversal of early atherosclerosis in metabolic syndrome by yoga - a randomized controlled trial. $J$ Yoga Phys Ther 2013, 3(1):132 
319. Manchanda SC, Narang R, Reddy KS, Sachdeva U, Prabhakaran D, Dharmanand S, Rajani M, Bijlani R: Retardation of coronary atherosclerosis with yoga lifestyle intervention. J Assoc Physicians India 2000, 48(7):687-694.

320. Mandanmohan JL, Udupa K, Bhavanani AB: Effect of yoga training on handgrip, respiratory pressures and pulmonary function. Indian J Physiol Pharmacol 2003, 47(4):387-392.

321. Manjunath N, Telles S: Influence of Yoga and Ayurveda on the measures of Gait, Balance and mobility in a geriatric population. Med Sci Monit 2007, 13(12):LE19-LE20.

322. Manjunath NK, Telles S: Improved performance in the Tower of London test following yoga. Indian J Physiol Pharmacol 2001, 45(3):351-354.

323. Manjunath NK, Telles S: Influence of Yoga and Ayurveda on self-rated sleep in a geriatric population. Indian J Med Res 2005, 121(5):683-690.

324. Manjunath NK, Telles S: Yoga for healthy aging. SENSE 2012, 2(2):32-41.

325. Manjunath RB, Varambally S, Thirthalli J, Basavaraddi IV, Gangadhar BN: Efficacy of yoga as an add-on treatment for in-patients with functional psychotic disorder. Indian J Psychiatry 2013, 55(Suppl 3):S374-S378.

326. Manocha R, Black D, Sarris J, Stough C: A randomized, controlled trial of meditation for work stress, anxiety and depressed mood in full-time workers. Evid Based Complement Alternat Med 2011, 2011:960583.

327. Manocha R, Marks GB, Kenchington P, Peters D, Salome CM: Sahaja yoga in the management of moderate to severe asthma: a randomised controlled trial. Thorax 2002, 57(2):110-115.

328. Marefat M, Peymanzad $H$, Alikhajeh $Y$ : The study of the effects of yoga exercises on addicts' depression and anxiety in rehabilitation period. Procedia Social and Behavioral Science 2011, 30:1494-1498.

329. Markil N, Whitehurst M, Jacobs PL, Zoeller RF: Yoga Nidra relaxation increases heart rate variability and is unaffected by a prior bout of Hatha yoga. J Altern Complement Med 2012, 18(10):953-958.

330. Martins RF, Pinto E, Silva JL: Treatment of pregnancy-related lumbar and pelvic girdle pain by the yoga method: a randomized controlled study. J Altern Complement Med 2014, 20(1):24-31.

331. McCaffrey R, Ruknui P, Hatthakit U, Kasetsomboon P: The effects of yoga on hypertensive persons in Thailand. Holist Nurs Pract 2005, 19(4):173-180.

332. Mclver S, O'Halloran P, McGartland M: Yoga as a treatment for binge eating disorder: a preliminary study. Complement Ther Med 2009 17(4):196-202

333. Mekonnen D, Mossie A: Clinical effects of yoga on asthmatic patients: a preliminary clinical trial. Ethiop J Health Sci 2010, 20(2):107-112.

334. Mendelson T, Greenberg MT, Dariotis JK, Gould LF, Rhoades BL, Leaf PJ: Feasibility and preliminary outcomes of a school-based mindfulness intervention for urban youth. J Abnorm Child Psychol 2010, 38(7):985-994.

335. Michalsen A, Jeitler M, Brunnhuber $S$, Lüdtke R, Büssing A, Musial F, Dobos $G$, Kessler $C$ : lyengar yoga for distressed women: A 3-armed randomized controlled trial. Evidence-based Complementary and Alternative Medicine 2012, 2012:408727.

336. Michalsen A, Traitteur $H$, Lüdtke R, Brunnhuber $S$, Meier $L$, Jeitler M, Büssing A, Kessler C: Yoga for chronic neck pain: a pilot randomized controlled clinical trial. J Pain 2012, 13(11):1122-1130.

337. Mitchell KS, Mazzeo SE, Rausch SM, Cooke KL: Innovative interventions for disordered eating: evaluating dissonance-based and yoga interventions. Int J Eat Disord 2007, 40(2):120-128.

338. Moadel AB, Shah C, Wylie-Rosett J, Harris MS, Patel SR, Hall CB, Sparano JA: Randomized controlled trial of yoga among a multiethnic sample of breast cancer patients: effects on quality of life. J Clin Oncol 2007, 25(28):4387-4395.

339. Monika SU, Ghildiyal A, Kala S, Srivastava N: Effect of Yoga Nidra on physiological variables in patients of menstrual disturbances of reproductive age group. Indian J Physiol Pharmacol 2012, 56(2):161-167.

340. Monro R, Power J, Coumar A, Nagarathna R, Dandona P: Yoga therapy for NIDDM: a controlled trial. Complementary Medical Research 1992, 6(2):66-68.

341. Mourya M, Mahajan AS, Singh NP, Jain AK: Effect of slow- and fastbreathing exercises on autonomic functions in patients with essential hypertension. J Altern Complement Med 2009, 15(7):711-717.

342. Murugesan R, Govindarajulu N, Bera TK: Effect of selected yogic practices on the management of hypertension. Indian J Physiol Pharmacol 2000, 44(2):207-210

343. Mustian KM, Sprod LK, Janelsins M, Peppone LJ, Palesh OG, Chandwani K, Reddy PS, Melnik MK, Heckler C, Morrow GR: Multicenter, randomized controlled trial of yoga for sleep quality among cancer survivors. J Clin Oncol 2013, 31(26):3233-3241.

344. Nagamatsu T, Kai Y, Kitabatake Y, Sensui H, Miyoshi Y: Effect of low intensity stretch exercise training program on sleep in middle-aged female workers. Bull Phys Fit Res Inst 2008, 106:1-8.

345. Nagamatsu T, Kitabatake $Y$, Sensui H: Effect of brief and low-intensity stretch exercise on core temperature, stress, and mood. Bull Phys Fit Res Inst 2012, 110:1-7.

346. Nagarathna R, Nagendra HR: Yoga for bronchial asthma: a controlled study. Br Med J (Clin Res Ed) 1985, 291(6502):1077-1079.

347. Nagarathna R, Usharani MR, Rao AR, Chaku R, Kulkarni R, Nagendra HR: Efficacy of yoga based life style modification program on Medication score and lipid profile in type 2 diabetes-a randomized control study. Int J Diabetes in Developing Countries 2012, 32(3):122-130.

348. Naveen KV, Nagarathna R, Nagendra HR, Telles S: Yoga breathing through a particular nostril increases spatial memory scores without lateralized effects. Psychol Rep 1997, 81(2):555-561.

349. Nemati $A$ : The effect of pranayama on test anxiety and test performance. Int J Yoga 2013, 6(1):55-60.

350. Newton KM, Reed SD, Guthrie KA, Sherman K, Booth-Laforce C, Caan B, Sternfeld B, Carpenter JS, Learman LA, Freeman EW, Cohen LS, Joffe $H_{\text {, }}$ Anderson GL, Larson JC, Hunt JR, Ensrud KE, LaCroix AZ: Efficacy of yoga for vasomotor symptoms: a randomized controlled trial. Menopause 2014, 21(4):339-346.

351. Nidhi R, Padmalatha $V$, Nagarathna R, Amritanshu R: Effect of holistic yoga program on anxiety symptoms in adolescent girls with polycystic ovarian syndrome: A randomized control trial. Int J Yoga 2012 5(2):112-117.

352. Nidhi R, Padmalatha V, Nagarathna R, Amritanshu R: Effect of yoga program on quality of life in adolescent polycystic ovarian syndrome: a randomized control trial. Appl Res Qual Life 2012, 8:373-383.

353. Nidhi R, Padmalatha V, Nagarathna R, Amritanshu R: Effects of a holistic yoga program on endocrine parameters in adolescents with polycystic ovarian syndrome: a randomized controlled trial. J Altern Complement Med 2013, 19(2):153-160.

354. Nidhi R, Padmalatha $V$, Nagarathna R, Ram A: Effect of a yoga program on glucose metabolism and blood lipid levels in adolescent girls with polycystic ovary syndrome. Int J Gynaecol Obstet 2012, 118(1):37-41.

355. Noggle JJ, Steiner NJ, Minami T, Khalsa SBS: Benefits of yoga for psychosocial well-being in a us high school curriculum: a preliminary randomized controlled trial. J Dev Behav Pediatr 2012, 33(3):193-201.

356. Norton GR, Johnson WE: A comparison of two relaxation procedures for reducing cognitive and somatic anxiety. J Behav Ther Exp Psychiatry 1983 14(3):209-214

357. Ohja K: A case study: investigation of Yoga's potential to treat breast cancer survivors facing cancer related fatigue. J Yoga Phys Ther 2012, 2(5):125

358. Oken BS, Kishiyama S, Zajdel D, Bourdette D, Carlsen J, Haas M, Hugos C, Kraemer DF, Lawrence J, Mass M: Randomized controlled trial of yoga and exercise in multiple sclerosis. Neurology 2004, 62(11):2058-2064.

359. Oken BS, Zajdel D, Kishiyama S, Flegal K, Dehen C, Haas M, Kraemer DF, Lawrence J, Leyva J: Randomized, controlled, six-month trial of yoga in healthy seniors: effects on cognition and quality of life. Altern Ther Health Med 2006, 12(1):40-47.

360. Oswal P, Nagarathna R, Ebnezar J, Nagendra HR: The effect of add-on yogic prana energization technique (YPET) on healing of fresh fractures: a randomized control study. J Altern Complement Med 2011, 17(3):253-258.

361. Paikkatt B, Singh AR, Singh PK, Jahan M: Efficacy of yoga therapy on subjective well-being and basic living skills of patients having chronic schizophrenia. Ind Psychiatry J 2012, 21(2):109-114.

362. Pal A, Srivastava N, Narain VS, Agrawal GG, Rani M: Effect of yogic intervention on the autonomic nervous system in the patients with coronary artery disease: a randomized controlled trial. East Mediterr Health J 2013, 19(5):452-458.

363. Pal A, Srivastava N, Tiwari S, Verma NS, Narain VS, Agrawal GG, Natu SM, Kumar K: Effect of yogic practices on lipid profile and body fat composition in patients of coronary artery disease. Complement Ther Med 2011, 19(3):122-127.

364. Pal GK, Madanmohan VS: Effect of short-term practice of breathing exercises on autonomic functions in normal human volunteers. Indian $J$ Med Res 2004, 120(2):115-121. 
365. Panjwani U, Gupta HL, Singh SH, Selvamurthy W, Rai UC: Effect of Sahaja yoga practice on stress management in patients of epilepsy. Indian $J$ Physiol Pharmacol 1995, 39(2):111-116.

366. Panjwani U, Selvamurthy W, Singh SH, Gupta HL, Mukhopadhyay S, Thakur $L$ : Effect of Sahaja yoga meditation on auditory evoked potentials (AEP) and visual contrast sensitivity (VCS) in epileptics. Appl Psychophysiol Biofeedback 2000, 25(1):1-12.

367. Panjwani U, Selvamurthy W, Singh SH, Gupta HL, Thakur L, Rai UC: Effect of Sahaja yoga practice on seizure control \& EEG changes in patients of epilepsy. Indian J Med Res 1996, 103:165-172.

368. Park J, McCaffrey R, Dunn D, Goodman R: Managing osteoarthritis: comparisons of chair yoga, Reiki, and education (pilot study). Holist Nurs Pract 2011, 25(6):316-326.

369. Patel C: Yoga and biofeedback in the management of hypertension. J Psychosom Res 1975, 19(5-6):355-360.

370. Patel C, North WR: Randomised controlled trial of yoga and bio feedback in management of hypertension. Lancet 1975, 2(7925):93-95.

371. Pomykala KL, Silverman DH, Geist CL, Voege P, Siddarth P, Nazarian N, Cyr NMS, Khalsa DS, Lavretsky H: A pilot study of the effects of meditation on regional brain metabolism in distressed dementia caregivers. Aging Health 2012, 8(5):509-516.

372. Prem V, Sahoo RC, Adhikari P: Comparison of the effects of Buteyko and pranayama breathing techniques on quality of life in patients with asthma - a randomized controlled trial. Clin Rehabil 2013, 27(2):133-141.

373. Pruthi S, Stan DL, Jenkins SM, Huebner M, Borg BA, Thomley BS, Cutshall SM, Singh R, Kohli S, Boughey JC, Lemaine V, Nes LS: A Randomized controlled pilot study assessing feasibility and impact of yoga practice on quality of life, mood, and perceived stress in women with newly diagnosed breast cancer. Global Advances In Health and Medicine 2012, 1(5):30-35.

374. Pullen PR, Nagamia SH, Mehta PK, Thompson WR, Benardot D, Hammoud R, Parrott JM, Sola S, Khan BV: Effects of yoga on inflammation and exercise capacity in patients with chronic heart failure. J Card Fail 2008, 14(5):407-413.

375. Pullen PR, Thompson WR, Benardot D, Brandon LJ, Mehta PK, Rifai L, Vadnais DS, Parrott JM, Khan BV: Benefits of yoga for African American heart failure patients. Med Sci Sports Exerc 2010, 42(4):651-657.

376. Raghavendra BR: Effects of yoga on natural killer cell counts in early breast cancer patients undergoing conventional treatment. Med Sci Monit 2008, 14(2):LE3-LE4.

377. Raghavendra RM, Nagarathna R, Nagendra HR, Gopinath KS, Srinath BS, Ravi $B D$, Patil S, Ramesh BS, Nalini R: Effects of an integrated yoga programme on chemotherapy-induced nausea and emesis in breast cancer patients. Eur J Cancer Care (Engl) 2007, 16(6):462-474.

378. Raghuraj P, Telles S: Muscle power, dexterity skill and visual perception in community home girls trained in yoga or sports and in regular school girls. Indian J Physiol Pharmacol 1997, 41(4):409-415.

379. Raghuraj P, Telles S: Immediate effect of specific nostril manipulating yoga breathing practices on autonomic and respiratory variables. Appl Psychophysiol Biofeedback 2008, 33(2):65-75.

380. Rahnama N, Namazizadeh M, Etemadifar M, Bambaeichi E, Arbabzadeh S, Sadeghipour HR: Effects of yoga on depression in women with multiple sclerosis. J Isfahan Medical School 2011, 29(136):1.

381. Rakhshaee Z: Effect of three yoga poses (cobra, cat and fish poses) in women with primary dysmenorrhea: a randomized clinical trial. J Pediatr Adolesc Gynecol 2011, 24(4):192-196.

382. Rakhshani A, Maharana S, Raghuram N, Nagendra HR, Venkatram P: Effects of integrated yoga on quality of life and interpersonal relationship of pregnant women. Qual Life Res 2010, 19(10):1447-1455.

383. Rakhshani A, Nagarathna R, Mhaskar R, Mhaskar A, Thomas A, Gunasheela S: The effects of yoga in prevention of pregnancy complications in high-risk pregnancies: a randomized controlled trial. Prev Med 2012, 55(4):333-340.

384. Rani K, Tiwari S, Singh U, Agrawal G, Ghildiyal A, Srivastava N: Impact of Yoga Nidra on psychological general wellbeing in patients with menstrual irregularities: A randomized controlled trial. Int J Yoga 2011, 4(1):20-25.

385. Rani K, Tiwari S, Singh U, Singh I, Srivastava N: Yoga Nidra as a complementary treatment of anxiety and depressive symptoms in patients with menstrual disorder. Int J Yoga 2012, 5(1):52-56.

386. Rani K, Tiwari SC, Singh U, Agrawal GG, Srivastava N: Six-month trial of yoga nidra in menstrual disorder patients: effects on somatoform symptoms. Ind Psychiatry J 2011, 20(2):97-102.
387. Rani M, Singh U, Agrawal GG, Natu SM, Kala S, Ghildiyal A, Srivastava N: Impact of Yoga Nidra on menstrual abnormalities in females of reproductive age. J Altern Complement Med 2013, 19(12):925-929.

388. Ranjbar F, Broomand M, Akbarzadeh A: The effect of yoga on anxiety symptoms in women with obsessive compulsive disorder. Life Science J 2013, 10(4):565-568.

389. Rao MR, Raghuram N, Nagendra HR, Gopinath KS, Srinath BS, Diwakar RB, Patil S, Bilimagga SR, Rao N, Varambally S: Anxiolytic effects of a yoga program in early breast cancer patients undergoing conventional treatment: a randomized controlled trial. Complement Ther Med 2009, 17(1):1-8.

390. Rao RM, Nagendra HR, Raghuram N, Vinay C, Chandrashekara S, Gopinath KS, Srinath BS: Influence of yoga on mood states, distress, quality of life and immune outcomes in early stage breast cancer patients undergoing surgery. Int J Yoga 2008, 1(1):11-20.

391. Rao RM, Nagendra HR, Raghuram N, Vinay C, Chandrashekara S, Gopinath KS, Srinath BS: Influence of yoga on postoperative outcomes and wound healing in early operable breast cancer patients undergoing surgery. Int J Yoga 2008, 1(1):33-41.

392. Rawal SB, Singh MV, Tyagi AK, Selvamurthy W, Chaudhuri BN: Effect of yogic exercises on thyroid function in subjects resident at sea level upon exposure to high altitude. Int J Biometeorol 1994, 38(1):44-47.

393. Ray US, Hegde KS, Selvamurthy W: Improvement in muscular efficiency as related to a standard task after yogic exercises in middle aged men. Indian J Med Res 1986, 83:343-348.

394. Ray US, Mukhopadhyaya S, Purkayastha SS, Asnani V, Tomer OS, Prashad R, Thakur L, Selvamurthy W: Effect of yogic exercises on physical and mental health of young fellowship course trainees. Indian J Physiol Pharmacol 2001, 45(1):37-53.

395. Ray US, Sinha B, Tomer OS, Pathak A, Dasgupta T, Selvamurthy W: Aerobic capacity \& perceived exertion after practice of Hatha yogic exercises. Indian J Med Res 2001, 114:215-221.

396. Reed SD, Guthrie KA, Newton KM, Anderson GL, Booth-Laforce C, Caan B, Carpenter JS, Cohen LS, Dunn AL, Ensrud KE, Freeman EW, Hunt JR, Joffe H, Larson JC, Learman LA, Rothenberg R, Seguin RA, Sherman KJ, Sternfeld BS, LaCroix AZ: RCT of yoga, exercise, and omega-3 supplements. Am J Obstet Gynecol 2014, 210(3):244.e1-11.

397. Rohini V, Pandey RS, Janakiramaiah N, Gangadhar BN, Vedamurthachar A A comparative study of full and partial Sudarshan Kriya Yoga (SKY) in major depressive disorder. NIMHANS J 2000, 18:53-57.

398. Sabina AB, Williams AL, Wall HK, Bansal S, Chupp G, Katz DL: Yoga intervention for adults with mild-to-moderate asthma: a pilot study. Ann Allergy Asthma Immunol 2005, 94(5):543-548.

399. Sakuma Y, Sasaki-Otomaru A, Ishida S, Kanoya Y, Arakawa C, Mochizuki Y, Seiishi $Y$, Sato C: Effect of a home-based simple yoga program in child-care workers: a randomized controlled trial. J Altern Complement Med 2012, 18(8):769-776.

400. Sanjay US, Kulkarni DD, Thakur GS: Effect of Yoga Practices on HS-CRP in Indian Railway Engine Drivers of Metropolis. SENSE 2012, 2(2):79-86.

401. Santaella DF, Devesa CR, Rojo MR, Amato MB, Drager LF, Casali KR, Montano $\mathrm{N}$, Lorenzi-Filho G: Yoga respiratory training improves respiratory function and cardiac sympathovagal balance in elderly subjects: a randomised controlled trial. BMJ Open 2011, 1(1):e000085.

402. Saper RB, Boah AR, Keosaian J, Cerrada C, Weinberg J, Sherman KJ: Comparing once- versus twice-weekly yoga classes for chronic Low back pain in predominantly Low income minorities: a randomized dosing trial. Evid Based Complement Alternat Med 2013, 2013:658030.

403. Saper RB, Sherman KJ, Cullum-Dugan D, Davis RB, Phillips RS, Culpepper L: Yoga for chronic low back pain in a predominantly minority population: a pilot randomized controlled trial. Altern Ther Health Med 2009, 15(6):18-27.

404. Saptharishi L, Soudarssanane M, Thiruselvakumar D, Navasakthi D, Mathanraj S, Karthigeyan M, Sahai A: Community-based randomized controlled trial of Non-pharmacological interventions in prevention and control of hypertension among young adults. Indian J Community Med 2009, 34(4):329-334.

405. Sareen S, Kumari V, Gajebasia KS, Gajebasia NK: Yoga: a tool for improving the quality of life in chronic pancreatitis. World J Gastroenterol 2007, 13(3):391-397.

406. Satyapriya M, Nagarathna R, Padmalatha V, Nagendra HR: Effect of integrated yoga on anxiety, depression \& well being in normal pregnancy. Complement Ther Clin Pract 2013, 19(4):230-236. 
407. Satyapriya M, Nagendra HR, Nagarathna R, Padmalatha V: Effect of integrated yoga on stress and heart rate variability in pregnant women. Int J Gynaecol Obstet 2009, 104(3):218-222.

408. Saxena T, Saxena M: The effect of various breathing exercises (pranayama) in patients with bronchial asthma of mild to moderate severity. Int J Yoga 2009, 2(1):22-25

409. Schmid AA, Van Puymbroeck M, Altenburger PA, Schalk NL, Dierks TA, Miller KK, Damush TM, Bravata DM, Williams LS: Poststroke balance improves with yoga: a pilot study. Stroke 2012, 43(9):2402-2407.

410. Sendhilkumar R, Gupta A, Nagarathna R, Taly AB: Effect of pranayama and meditation as an add-on therapy in rehabilitation of patients with Guillain-Barre syndrome-a randomized control pilot study. Disabil Rehabil 2013, 35(1):57-62.

411. Seo DY, Lee S, Figueroa A, Kim HK, Baek YH, Kwak YS, Kim N, Choi TH, Rhee BD, Ko KS, Park BJ, Park SY, Han J: Yoga training improves metabolic parameters in obese boys. Korean J Physiol Pharmacol 2012, 16(3):175-180.

412. Shaffer HJ, LaSalvia TA, Stein JP: Comparing Hatha yoga with dynamic group psychotherapy for enhancing methadone maintenance treatment: a randomized clinical trial. Altern Ther Health Med 1997, 3(4):57-66.

413. Shahab L, Sarkar BK, West R: The acute effects of yogic breathing exercises on craving and withdrawal symptoms in abstaining smokers. Psychopharmacology (Berl) 2013, 225(4):875-882.

414. Shahidi M, Mojtahed A, Modabbernia A, Mojtahed M, Shafiabady A, Delavar A, Honari $\mathrm{H}$ : Laughter yoga versus group exercise program in elderly depressed women: a randomized controlled trial. Int J Geriatr Psychiatry 2011, 26(3):322-327.

415. Shankarapillai R, Nair MA, George R: The effect of yoga in stress reduction for dental students performing their first periodontal surgery: A randomized controlled study. Int J Yoga 2012, 5(1):48-51.

416. Shannahoff-Khalsa DS, Ray LE, Levine S, Gallen CC, Schwartz BJ, Sidorowich $\mathrm{JJ}$ : Randomized controlled trial of yogic meditation techniques for patients with obsessive-compulsive disorder. CNS Spectr 1999, 4(12):34-47.

417. Shantakumari N, Sequeira S, El deeb R: Effects of a yoga intervention on lipid profiles of diabetes patients with dyslipidemia. Indian Heart J 2013, 65(2):127-131

418. Sharma VK, Das S, Mondal S, Goswami U: Comparative effect of Sahaj Yoga on EEG in patients of major depression and healthy subjects. Biomedicine 2007, 27(3):95-99.

419. Sharma VK, Das S, Mondal S, Goswami U: Effect of Sahaj yoga on autonomic functions in healthy subjects and patients of major depression. Biomedicine 2008, 28(2):139-141.

420. Sharma VK, Das S, Mondal S, Goswami U, Gandhi A: Effect of Sahaj Yoga on neuro-cognitive functions in patients suffering from major depression. Indian J Physiol Pharmacol 2006, 50(4):375-383.

421. Sharma VK, Das S, Mondal S, Goswampi U, Gandhi A: Effect of Sahaj Yoga on depressive disorders. Indian J Physiol Pharmacol 2005, 49(4):462-468.

422. Sharma VK, Rajajeyakumar M, Velkumary S, Subramanian SK, Bhavanani AB, Madanmohan SA, Thangavel D: Effect of fast and slow pranayama practice on cognitive functions in healthy volunteers. J Clinical and Diagnostic Res 2014, 8(1):10-13.

423. Sharma VK, Trakroo M, Subramaniam V, Rajajeyakumar M, Bhavanani AB, Sahai A: Effect of fast and slow pranayama on perceived stress and cardiovascular parameters in young health-care students. Int J Yoga 2013, 6(2):104-110.

424. Shelov DV, Suchday S, Friedberg JP: A pilot study measuring the impact of yoga on the trait of mindfulness. Behav Cogn Psychother 2009, 37(5):595-598.

425. Sherman KJ, Cherkin DC, Erro J, Miglioretti DL, Deyo RA: Comparing yoga, exercise, and a self-care book for chronic low back pain: a randomized, controlled trial. Ann Intern Med 2005, 143(12):849-856.

426. Sherman KJ, Cherkin DC, Wellman RD, Cook AJ, Hawkes RJ, Delaney K, Deyo $\mathrm{RA}$ : A randomized trial comparing yoga, stretching, and a self-care book for chronic low back pain. Arch Intern Med 2011, 171(22):2019-2026.

427. Siedentopf F, Utz-Billing I, Gairing S, Schoenegg W, Kentenich H, Kollak I: Yoga for patients with early breast cancer and its impact on quality of life - a randomized controlled trial. Geburtshilfe Frauenheilkd 2013, 73(4):311-317.

428. Singh S, Soni R, Singh KP, Tandon OP: Effect of yoga practices on pulmonary function tests including transfer factor of lung for carbon monoxide (TLCO) in asthma patients. Indian J Physiol Pharmacol 2012, 56(1):63-68
429. Singh V, Wisniewski A, Britton J, Tattersfield A: Effect of yoga breathing exercises (pranayama) on airway reactivity in subjects with asthma. Lancet 1990, 335(8702):1381-1383.

430. Singh VK, Bhandari RB, Rana BB: Effect of yogic package on rheumatoid arthritis. Indian J Physiol Pharmacol 2011, 55(4):329-335

431. Skoro-Kondza L, Tai SS, Gadelrab R, Drincevic D, Greenhalgh T: Community based yoga classes for type 2 diabetes: an exploratory randomised controlled trial. BMC Health Serv Res 2009, 9:33.

432. Smith C, Hancock H, Blake-Mortimer J, Eckert K: A randomised comparative trial of yoga and relaxation to reduce stress and anxiety. Complement Ther Med 2007, 15(2):77-83.

433. Sobana R, Parthasarathy S, Duraisamy JK, Vadivel S: The effect of yoga therapy on selected psychological variables among male patients with insomnia. J Clin Diagn Res 2013, 7(1):55-57.

434. Sodhi C, Singh S, Dandona PK: A study of the effect of yoga training on pulmonary functions in patients with bronchial asthma. Indian J Physiol Pharmacol 2009, 53(2):169-174.

435. Soni R, Munish K, Singh K, Singh S: Study of the effect of yoga training on diffusion capacity in chronic obstructive pulmonary disease patients: A controlled trial. Int J Yoga 2012, 5(2):123-127.

436. Stachenfeld NS, Mack GW, DiPietro L, Morocco TS, Jozsi AC, Nadel ER: Regulation of blood volume during training in post-menopausal women. Med Sci Sports Exerc 1998, 30(1):92-98.

437. Stoller CC, Greuel JH, Cimini LS, Fowler MS, Koomar JA: Effects of sensoryenhanced yoga on symptoms of combat stress in deployed military personnel. Am J Occup Ther 2012, 66(1):59-68.

438. Streeter CC, Whitfield TH, Owen L, Rein T, Karri SK, Yakhkind A, Perlmutter R, Prescot A, Renshaw PF, Ciraulo DA, Jensen JE: Effects of yoga versus walking on mood, anxiety, and brain GABA levels: a randomized controlled MRS study. J Altern Complement Med 2010, 16(11):1145-1152.

439. Subramanian $H$, Soudarssanane MB, Jayalakshmy $R$, Thiruselvakumar $D$, Navasakthi D, Sahai A, Saptharishi L: Non-pharmacological Interventions in Hypertension: A Community-based Cross-over Randomized Controlled Trial. Indian J Community Med 2011, 36(3):191-196.

440. Subramanian S, Elango T, Malligarjunan H, Kochupillai V, Dayalan H: Role of sudarshan kriya and pranayam on lipid profile and blood cell parameters during exam stress: A randomized controlled trial. Int J Yoga 2012, 5(1):21-27.

441. Tandon MK: Adjunct treatment with yoga in chronic severe airways obstruction. Thorax 1978, 33(4):514-517.

442. Taneja I, Deepak KK, Poojary G, Acharya IN, Pandey RM, Sharma MP: Yogic versus conventional treatment in diarrhea-predominant irritable bowel syndrome: a randomized control study. Appl Psychophysiol Biofeedback 2004, 29(1):19-33.

443. Tekur P, Chametcha S, Hongasandra RN, Raghuram N: Effect of yoga on quality of life of clbp patients: A randomized control study. Int J Yoga 2010, 3(1):10-17.

444. Tekur P, Nagarathna R, Chametcha S, Hankey A, Nagendra HR: A comprehensive yoga programs improves pain, anxiety and depression in chronic low back pain patients more than exercise: an RCT. Complement Ther Med 2012, 20(3):107-118

445. Tekur P, Singphow C, Nagendra HR, Raghuram N: Effect of short-term intensive yoga program on pain, functional disability and spinal flexibility in chronic low back pain: a randomized control study. J Altern Complement Med 2008, 14(6):637-644.

446. Telles S, Bhardwaj AK, Kumar S, Kumar N, Balkrishna A: Performance in a substitution task and state anxiety following yoga in army recruits. Psychol Rep 2012, 110(3):963-976.

447. Telles S, Dash M, Manjunath NK, Deginal R, Naveen KV: Effect of yoga on visual perception and visual strain. J Mod Opt 2007, 54(9):1379-1383.

448. Telles S, Dash M, Naveen KV: Effect of yoga on musculoskeletal discomfort and motor functions in professional computer users. Work 2009, 33 (3):297-306.

449. Telles $S$, Joshi M, Somvanshi P: Yoga breathing through a particular nostril is associated with contralateral event-related potential changes. Int J Yoga 2012, 5(2):102-107.

450. Telles S, Nagarathna R, Nagendra HR: Breathing through a particular nostril can alter metabolism and autonomic activities. Indian J Physiol Pharmacol 1994, 38(2):133-137.

451. Telles S, Nagarathna R, Nagendra HR: Physiological measures of right nostril breathing. J Altern Complement Med 1996, 2(4):479-484. 
452. Telles S, Narendran S, Raghuraj P, Nagarathna R, Nagendra HR: Comparison of changes in autonomic and respiratory parameters of girls after yoga and games at a community home. Percept Mot Skills 1997, 84(1):251-257.

453. Telles S, Naveen KV: Effect of yoga on somatic indicators of distress in professional computer users. Med Sci Monit 2006, 12(10):LE21-LE22.

454. Telles S, Naveen KV, Dash M, Deginal R, Manjunath NK: Effect of yoga on self-rated visual discomfort in computer users. Head Face Med 2006, 2:46.

455. Telles S, Raghavendra BR, Naveen KV, Manjunath NK, Kumar S, Subramanya $P$ : Changes in autonomic variables following two meditative states described in yoga texts. J Altern Complement Med 2013, 19(1):35-42.

456. Telles S, Raghuraj P, Maharana S, Nagendra HR: Immediate effect of three yoga breathing techniques on performance on a letter-cancellation task. Percept Mot Skills 2007, 104(3 Pt 2):1289-1296.

457. Telles S, Singh N, Balkrishna A: Finger dexterity and visual discrimination following two yoga breathing practices. Int J Yoga 2012, 5(1):37-41.

458. Telles S, Singh N, Bhardwaj AK, Kumar A, Balkrishna A: Effect of yoga or physical exercise on physical, cognitive and emotional measures in children: a randomized controlled trial. Child Adolesc Psychiatry Ment Health 2013, 7(1):37.

459. Telles S, Singh N, Joshi M, Balkrishna A: Post traumatic stress symptoms and heart rate variability in Bihar flood survivors following yoga: a randomized controlled study. BMC Psychiatry 2010, 10:18.

460. Telles S, Srinivas RB: Autonomic and respiratory measures in children with impaired vision following yoga and physical activity programs. Int $J$ Rehabilitation \& Health 1998, 4(2):117-122.

461. Telles S, Yadav A, Kumar N, Sharma S, Visweshwaraiah NK, Balkrishna A: Blood pressure and Purdue pegboard scores in individuals with hypertension after alternate nostril breathing, breath awareness, and no intervention. Med Sci Monit 2013, 19:61-66.

462. Tharion E, Samuel P, Rajalakshmi R, Gnanasenthil G, Subramanian RK Influence of deep breathing exercise on spontaneous respiratory rate and heart rate variability: a randomised controlled trial in healthy subjects. Indian J Physiol Pharmacol 2012, 56(1):80-87.

463. Tiedemann A, O'Rourke S, Sesto R, Sherrington C: A 12-week lyengar yoga program improved balance and mobility in older community-dwelling people: a pilot randomized controlled trial. J Gerontol A Biol Sci Med Sci 2013, 68(9):1068-1075.

464. Tilbrook HE, Cox H, Hewitt CE, Kang'ombe AR, Chuang LH, Jayakody S, Aplin JD, Semlyen A, Trewhela A, Watt I, Torgerson DJ: Yoga for chronic low back pain: a randomized trial. Ann Intern Med 2011, 155(9):569-578.

465. Toise SC, Sears SF, Schoenfeld MH, Blitzer ML, Marieb MA, Drury JH, Slade MD, Donohue TJ: Psychosocial and cardiac outcomes of yoga for ICD patients: a randomized clinical control trial. Pacing Clin Electrophysiol 2014, 37(1):48-62

466. Tracy BL, Hart CEF: Bikram yoga training and physical fitness in healthy young adults. J Strength Cond Res 2013, 27(3):822-830.

467. Trakroo M, Bhavanani AB, Pal GK, Udupa K, Krishnamurthy N: A comparative study of the effects of asan, pranayama and asan-pranayama training on neurological and neuromuscular functions of Pondicherry police trainees. Int J Yoga 2013, 6(2):96-103.

468. Turankar AV, Jain S, Patel SB, Sinha SR, Joshi AD, Vallish BN, Mane PR, Turankar SA: Effects of slow breathing exercise on cardiovascular functions, pulmonary functions \& galvanic skin resistance in healthy human volunteers - a pilot study. Indian J Med Res 2013, 137(5):916-921.

469. Madanmohan UK, Bhavanani AB, Vijayalakshmi P, Krishnamurthy N: Effect of pranayam training on cardiac function in normal young volunteers. Indian J Physiol Pharmacol 2003, 47(1):27-33.

470. Umadevi P, Ramachandra S, Varambally S, Philip M, Gangadhar BN: Effect of yoga therapy on anxiety and depressive symptoms and quality-of-life among caregivers of in-patients with neurological disorders at a tertiary care center in India: A randomized controlled trial. Indian J Psychiatry 2013, 55(7):S385-s389.

471. Vadiraja HS, Rao MR, Nagarathna R, Nagendra HR, Rekha M, Vanitha N, Gopinath KS, Srinath BS, Vishweshwara MS, Madhavi YS, Ajaikumar BS, Bilimagga SR, Rao N: Effects of yoga program on quality of life and affect in early breast cancer patients undergoing adjuvant radiotherapy: a randomized controlled trial. Complement Ther Med 2009, 17:274-280.

472. Vadiraja HS, Raghavendra RM, Nagarathna R, Nagendra HR, Rekha M Vanitha N, Gopinath KS, Srinath BS, Vishweshwara MS, Madhavi YS, Ajaikumar BS, Ramesh BS, Nalini R, Kumar V: Effects of a yoga program on cortisol rhythm and mood states in early breast cancer patients undergoing adjuvant radiotherapy: a randomized controlled trial. Integr Cancer Ther 2009, 8(1):37-46.

473. Vadiraja HS, Rao RM, Hongasandra NR, Nagarathna R, Rekha M, Vanitha N, Kodaganuru GS, Srinath BS, Vishweshwara MS, Madhavi YS, Ajaikumar BS, Ramesh BS, Nalini R, Kumar V: Effects of yoga on symptom management in breast cancer patients: A randomized controlled trial. Int J Yoga 2009, 2(2):73-79.

474. Vaishali K, Kumar KV, Adhikari P, UnniKrishnan B: Effects of yoga-based program on glycosylated hemoglobin level serum lipid profile in community dwelling elderly subjects with chronic type 2 diabetes mellitus - A randomized controlled trial. Physical Occupat Ther Geriatrics 2012, 30(1):22-30.

475. Valentine ER, Meyer-Dinkgräfe D, Acs V, Wasley D: Exploratory investigation of South Indian techniques and neurolinguistic programming as methods of reducing stage fright in actors. Med Probl Perform Art 2006 21(3):126-136.

476. Van Puymbroeck M, Payne LL, Hsieh PC: A phase I feasibility study of yoga on the physical health and coping of informal caregivers. Evid Based Complement Alternat Med 2007, 4(4):519-529.

477. Vancampfort D, De Hert M, Knapen J, Wampers M, Demunter H, Deckx S, Maurissen K, Probst M: State anxiety, psychological stress and positive well-being responses to yoga and aerobic exercise in people with schizophrenia: a pilot study. Disabil Rehabil 2011, 33(8):684-689.

478. Vandana B, Saraswathy L, Pillai GK, Sunadaram KR, Kumar H: Meditation induces a positive response during stress events in young Indian adults. Int J Yoga 2011, 2011(4):2.

479. Varambally S, Gangadhar BN, Thirthalli J, Jagannathan A, Kumar S, Venkatasubramanian G, Muralidhar D, Subbakrishna DK, Nagendra HR: Therapeutic efficacy of add-on yogasana intervention in stabilized outpatient schizophrenia: Randomized controlled comparison with exercise and waitlist. Indian J Psychiatry 2012, 54(3):227-232.

480. Varambally S, Vidyendaran S, Sajjanar M, Thirthalli J, Hamza A, Nagendra HR, Gangadhar BN: Yoga-based intervention for caregivers of outpatients with psychosis: a randomized controlled pilot study. Asian J Psychiatr 2013, 6(2):141-145.

481. Veale D, Le Fevre K, Pantelis C, De Souza V, Mann A, Sargeant A: Aerobic exercise in the adjunctive treatment of depression: a randomized controlled trial. J R Soc Med 1992, 85:541-544.

482. Vedamurthachar A, Janakiramaiah N, Hegde JM, Shetty TK, Subbakrishna DK, Sureshbabu SV, Gangadhar BN: Antidepressant efficacy and hormonal effects of Sudarshana Kriya Yoga (SKY) in alcohol dependent individuals. $J$ Affect Disord 2006, 94(1-3):249-253.

483. Vedanthan PK, Kesavalu LN, Murthy KC, Duvall K, Hall MJ, Baker S, Nagarathna S: Clinical study of yoga techniques in university students with asthma: a controlled study. Allergy Asthma Proc 1998, 19(1):3-9.

484. Velikonja O, Curic K, Ozura A, Jazbec SS: Influence of sports climbing and yoga on spasticity, cognitive function, mood and fatigue in patients with multiple sclerosis. Clin Neurol Neurosurg 2010, 112(7):597-601.

485. Vempati R, Bijlani RL, Deepak KK: The efficacy of a comprehensive lifestyle modification programme based on yoga in the management of bronchial asthma: a randomized controlled trial. BMC Pulm Med 2009, 9:37

486. Visceglia $E$, Lewis S: Yoga therapy as an adjunctive treatment for schizophrenia: a randomized, controlled pilot study. J Altern Complement Med 2011, 17(7):601-607.

487. Visweswaraiah NK, Telles S: Randomized trial of yoga as a complementary therapy for pulmonary tuberculosis. Respirology 2004, 9(1):96-101.

488. Vogler J, O'Hara L, Gregg J, Burnell F: The impact of a short-term iyengar yoga program on the health and well-being of physically inactive older adults. Int J Yoga Therap 2011, 21:61-72.

489. White LS: Reducing stress in school-age girls through mindful yoga. J Pediatr Health Care 2012, 26(1):45-56.

490. Williams K, Abildso C, Steinberg L, Doyle E, Epstein B, Smith D, Hobbs G, Gross R, Kelley G, Cooper L: Evaluation of the effectiveness and efficacy of lyengar yoga therapy on chronic low back pain. Spine (Phila Pa 1976) 2009, 34(19):2066-2076.

491. Williams KA, Petronis J, Smith D, Goodrich D, Wu J, Ravi N, Doyle EJ, Gregory Juckett R, Munoz Kolar M, Gross R, Steinberg L: Effect of lyengar yoga therapy for chronic low back pain. Pain 2005, 115(1-2):107-117.

492. Wolever RQ, Kusnick CA, Bobinet KJ, McCabe K, Mackenzie ER, Fekete E, Baime M: Effective and viable mind-body stress reduction in the 
workplace: a randomized controlled trial. $J$ Occup Health Psychol 2012, 17(2):246-258.

493. Woolery A, Myers H, Sternlieb B, Zeltzer L: A yoga intervention for young adults with elevated symptoms of depression. Altern Ther Health Med 2004, 10(2):60-63.

494. Xie J, Lin Y, Guo C, Chen F: Study on influences of yoga on quality of life of schizophrenic inpatients. J Nursing (China) 2006, 13:9-11.

495. Yang K, Bernardo LM, Sereika SM, Conroy MB, Balk J, Burke LE: Utilization of 3-month yoga program for adults at high risk for type 2 diabetes: a pilot study. Evid Based Complement Alternat Med 2011, 2011:257891.

496. Yogitha B, Ebnezar J: Effect of yoga therapy and conventional treatment in the management of common neck pain - a comparative study. J Yoga Phys Ther 2012, 2:108.

497. Yogitha B, Nagarathna R, John E, Nagendra HR: Complimentary effect of yogic sound resonance relaxation technique in patients with common neck pain. Int J Yoga 2010, 3(1):18-25.

498. Yuille JC, Sereda L: Positive effects of meditation: A limited generalization? J Appl Psychol 1980, 65(3):333-340

499. Yurtkuran M, Alp A, Yurtkuran M, Dilek K: A modified yoga-based exercise program in hemodialysis patients: a randomized controlled study. Complement Ther Med 2007, 15(3):164-171.

500. Zhuang SM, An SH, Zhao Y: Yoga effects on mood and quality of life in Chinese women undergoing heroin detoxification: a randomized controlled trial. Nurs Res 2013, 62(4):260-268.

501. Cramer H, Lauche R, Langhorst J, Dobos G: Effectiveness of yoga for menopausal symptoms: a systematic review and meta-analysis of randomized controlled trials. Evid Based Complement Alternat Med 2012, 2012:863905.

502. Cramer H, Posadzki P, Dobos G, Langhorst J: Yoga for asthma: a systematic review and meta-analysis. Ann Allergy Asthma Immunol 2014, 112(6):503-510 e505.

503. Cramer H, Lange S, Klose P, Paul A, Dobos G: Yoga for breast cancer patients and survivors: a systematic review and meta-analysis. BMC Cancer 2012, 12:412.

504. Cramer H, Lange S, Klose P, Paul A, Dobos G: Can yoga improve fatigue in breast cancer patients? A systematic review. Acta Oncol 2012, 51(4):559-560

505. Uebelacker LA, Epstein-Lubow G, Gaudiano BA, Tremont G, Battle CL, Miller IW: Hatha yoga for depression: critical review of the evidence for efficacy, plausible mechanisms of action, and directions for future research. J Psychiatr Pract 2010, 16(1):22-33.

506. Cramer H, Lauche R, Langhorst J, Dobos G: Yoga for depression: a systematic review and meta-analysis. Depress Anxiety 2013, 30(11):1068-1083.

507. Aljasir B, Bryson M, Al-Shehri B: Yoga practice for the management of type II diabetes mellitus in adults: a systematic review. Evid Based Complement Alternat Med 2010, 7(4):399-408

508. Cramer H, Lauche R, Haller H, Steckhan N, Michalsen A, Dobos G: Effects of yoga on cardiovascular disease risk factors: a systematic review and meta-analysis. Int J Cardiol 2014, 173(2):170-183.

509. Cramer H, Lauche R, Haller H, Dobos G: A systematic review and metaanalysis of yoga for low back pain. Clin J Pain 2013, 29(5):450-460

510. Holtzman S, Beggs RT: Yoga for chronic low back pain: a meta-analysis of randomized controlled trials. Pain Res Manag 2013, 18(5):267-272.

511. Cramer H, Haller H, Lauche R, Steckhan N, Michalsen A, Dobos G. A systematic review and meta-analysis of yoga for hypertension. Am J Hypertens 2014, 27(9):1146-1151.

512. Hagins M, States R, Selfe T, Innes $K$ : Effectiveness of yoga for hypertension: systematic review and meta-analysis. Evid Based Complement Alternat Med 2013, 2013:649836

513. Posadzki P, Cramer H, Kuzdzal A, Lee MS, Ernst E: Yoga for hypertension: A systematic review of randomized clinical trials. Complement Ther Med 2014, 22(3):511-522.

514. Curtis K, Weinrib A, Katz J: Systematic review of yoga for pregnant women: current status and future directions. Evid Based Complement Alternat Med 2012, 2012:715942.

515. Cramer H, Lauche R, Klose P, Langhorst J, Dobos G: Yoga for schizophrenia: a systematic review and meta-analysis. BMC Psychiatry 2013, 13(1):32.

516. Lee MS, Kim JI, Ha JY, Boddy K, Ernst E: Yoga for menopausal symptoms: a systematic review. Menopause 2009, 16(3):602-608.
517. Senders A, Wahbeh $H$, Spain R, Shinto L: Mind-body medicine for multiple sclerosis: a systematic review. Autoimmune Dis 2012, 2012:567324.

518. Sherman KJ: Guidelines for developing yoga interventions for randomized trials. Evid Based Complement Alternat Med 2012, 2012:143271.

519. Kinser PA, Robins JL: Control group design: enhancing rigor in research of mind-body therapies for depression. Evid Based Complement Alternat Med 2013, 2013:140467.

520. Lansky EP, St Louis EK: Transcendental meditation: a double-edged sword in epilepsy? Epilepsy Behav 2006, 9(3):394-400

521. Kabat-Zinn J: Full catastrophe living: using the wisdom of your body and mind to face stress, pain, and illness. New York, NY: Delta Trade Paperback/Bantam Dell; 1990.

doi:10.1186/1472-6882-14-328

Cite this article as: Cramer et al:: Characteristics of randomized

controlled trials of yoga: a bibliometric analysis. BMC Complementary and Alternative Medicine 2014 14:328.

\section{Submit your next manuscript to BioMed Central and take full advantage of:}

- Convenient online submission

- Thorough peer review

- No space constraints or color figure charges

- Immediate publication on acceptance

- Inclusion in PubMed, CAS, Scopus and Google Scholar

- Research which is freely available for redistribution 